\title{
Collaborative Entrepreneurship and Building Small Business Communities in The Nigerian Fashion Design Industry
}

\author{
Damilola T. Fasinu \\ West Virginia Uiversity, dtf0002@mix.wvu.edu
}

Follow this and additional works at: https://researchrepository.wvu.edu/etd

Part of the Arts and Humanities Commons, Business Commons, and the Social and Behavioral

\section{Recommended Citation}

Fasinu, Damilola T., "Collaborative Entrepreneurship and Building Small Business Communities in The Nigerian Fashion Design Industry" (2020). Graduate Theses, Dissertations, and Problem Reports. 7541. https://researchrepository.wvu.edu/etd/7541

This Thesis is protected by copyright and/or related rights. It has been brought to you by the The Research Repository @ WVU with permission from the rights-holder(s). You are free to use this Thesis in any way that is permitted by the copyright and related rights legislation that applies to your use. For other uses you must obtain permission from the rights-holder(s) directly, unless additional rights are indicated by a Creative Commons license in the record and/ or on the work itself. This Thesis has been accepted for inclusion in WVU Graduate Theses, Dissertations, and Problem Reports collection by an authorized administrator of The Research Repository @ WVU. For more information, please contact researchrepository@mail.wvu.edu. 
Collaborative Entrepreneurship and Building Small Business Communities in The Nigerian Fashion Design Industry

Damilola T. Fasinu

\begin{abstract}
A thesis submitted to the
Davis College of Agriculture, Natural Resources and Design

at West Virginia University

in partial fulfillment of the requirements for the degree of
\end{abstract}

\author{
Master of Science \\ in \\ Design \& Merchandising \\ Katie Jones, Ph.D., Chair \\ Colleen Moretz, MFA. \\ Angela Uriyo, Ph.D. \\ Jessica Blythe, Ph.D.
}

School of Design and Community Development

Morgantown, West Virginia
2019

Keywords: Entrepreneurship, Collaboration, Collaborative entrepreneurship, Fashion Entrepreneur

Copyright 2019 Damilola T. Fasinu 


\begin{abstract}
Collaborative Entrepreneurship and Building Small Business Communities in The Nigerian Fashion Design Industry
\end{abstract}

Damilola T. Fasinu

A critical part of being an entrepreneur is the ability to work with others. Researchers who explore entrepreneurship acknowledge collaboration and information sharing as key as more obvious skills such as opportunity recognition and determination. Collaboration allows a firm to be entrepreneurial and constantly innovative by exploring new markets. Continuous innovation and market exploration are the foundation of collaboration. Entrepreneurship is a critical factor in the growth of developing countries, as it enables a country to grow economically and encourages sustainable business activity. Therefore, this study explores the collaborative entrepreneurship of communities of some small businesses in Nigeria for their competitive advantage. The objective of the study is to identify the challenges and opportunities of Nigerian fashion entrepreneurs, explore perceptions of collaborative relationships, and to examine best practices for building a collaborative community of design professionals. An inductive qualitative research approach was used to explore the challenges, opportunities, and best practices used in this community. To better understand these entrepreneurs lived experiences, a semi-structured phone interview was used to gather information. Participants' recruiting occurred through purposive sampling from the Fashionpreneur group and non-fashionpreneur group members. The Fashionpreneur group is a community of Nigerian fashion designers created for the purpose of resource sharing for their business growth. The results of this research recommend best practices in creating a successful collaborative relationship for the designer's competitive advantage. The result is presented to the admins of the Fashionpreneur group and inform future research and intervention. 


\section{ACKNOWLEDGMENTS}

I first give thanks and praise to God, who has given me strength, determination, tenacity, and hope throughout my graduate education. Without my faith and the guidance I receive from Him, I would not have this passion and vision to become an advocate for others who need advocacy. I would also like to express my sincere appreciation to everyone who supported me, encouraged me, and believed in me during my graduate career and dissertation process. My family, who lifted me when I wanted to give up, my husband, who supported my ideas and pushed me to research my passion, and to my little princess that endured my divided attention during this study, I love you. To my professors, particularly my advisor, Prof. Colleen Moretz, and my chair, Dr. Jones, who guided and molded my research interests to recommend best practices for business sustainability. Finally, I would like to thank the eleven incredible entrepreneurs who took the time to share their life experiences to highlight the need for collaboration for best business practices. Your time and investment in my research study are so much appreciated, and I thank each of you for sharing pieces of you with the readers. 


\section{DEDICATION}

I dedicate this dissertation to all entrepreneurs coping with business challenges and are pushing through against all the odds. May your voices and your sacrifices one day be heard, and your businesses celebrated. 


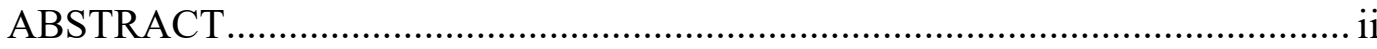

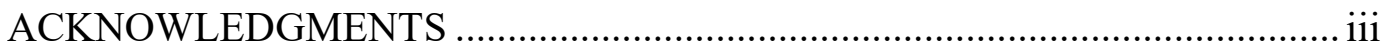

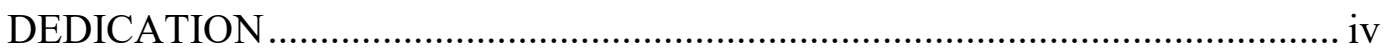

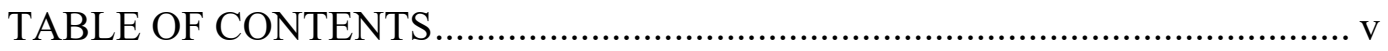

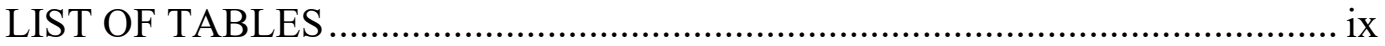

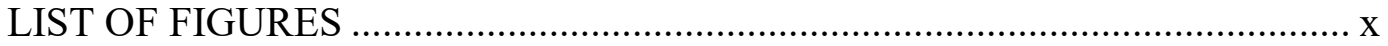

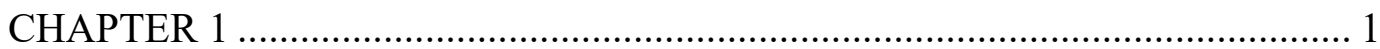

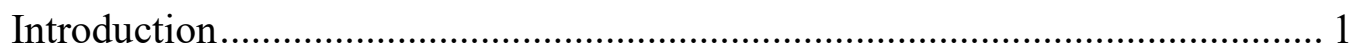

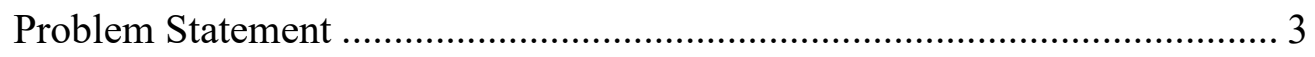

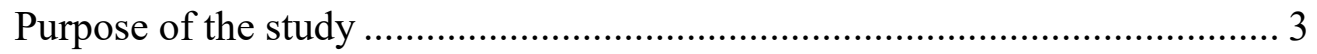

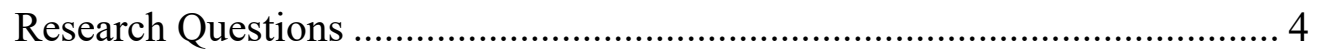

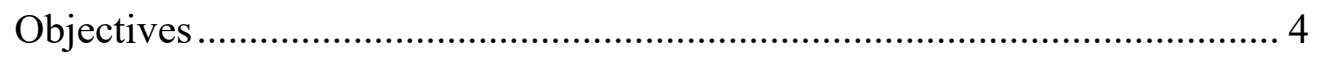

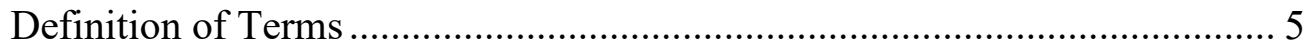

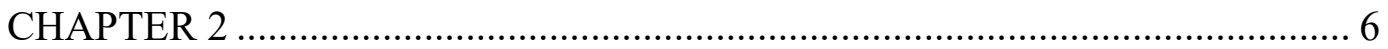

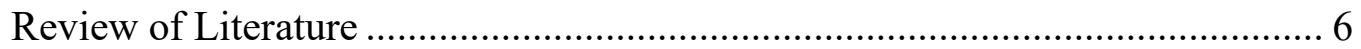

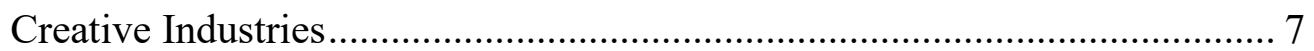

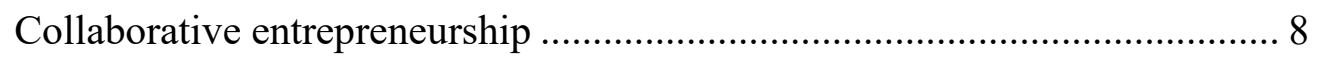

Theoretical Framework for Collaboration.................................................. 10

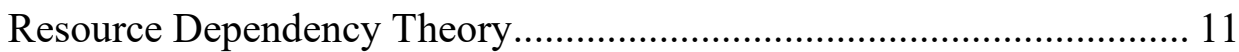

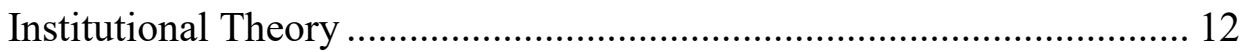


Network Theory

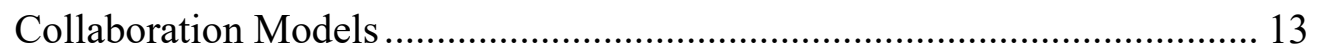

Administrative Coordination ............................................................... 14

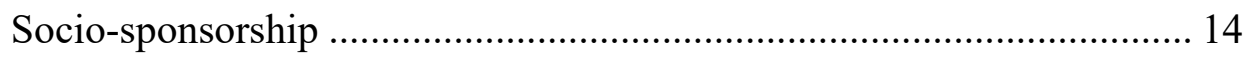

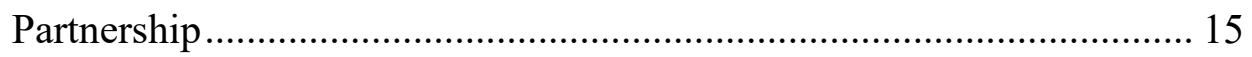

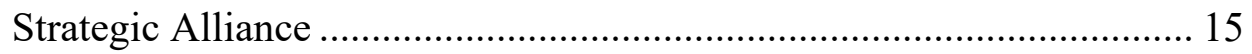

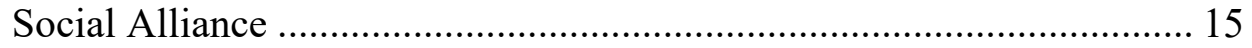

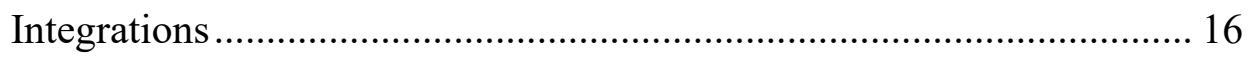

Themes Common Across Research in Collaboration Models........................ 17

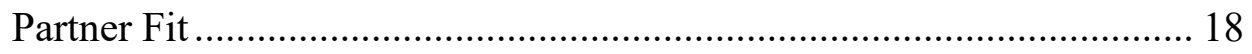

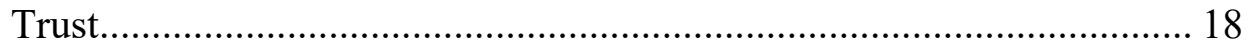

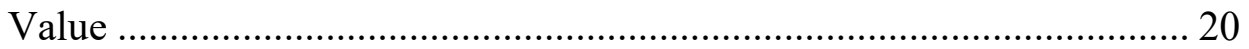

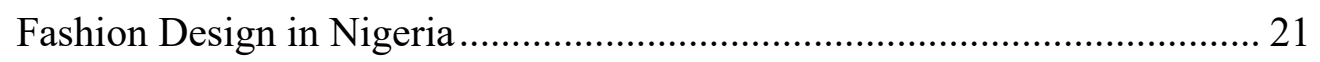

Nigerian Fashion Market...................................................................... 22

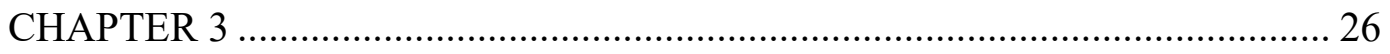

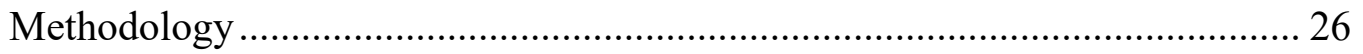

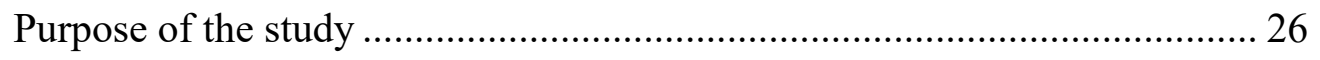

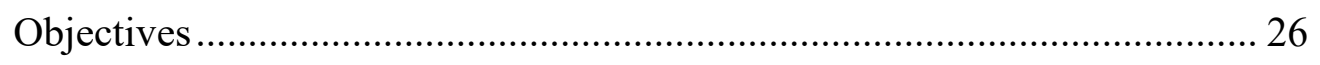

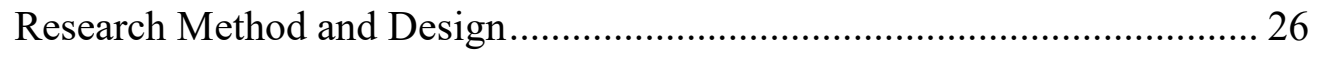

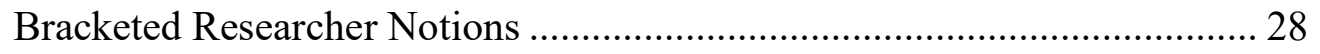


Population and Participant Recruitment

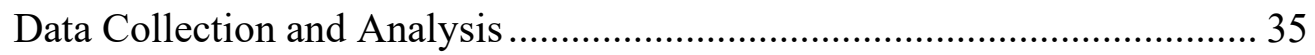

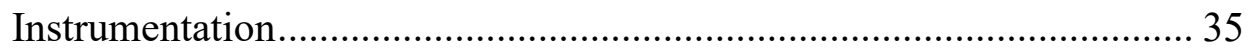

Data Analysis ........................................................................... 36

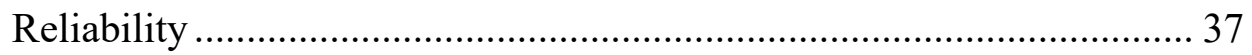

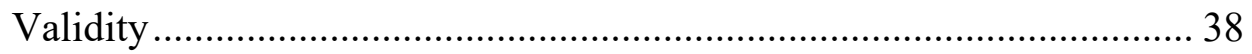

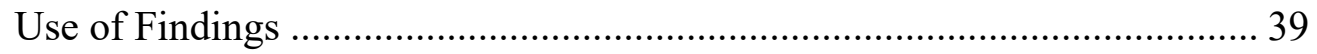

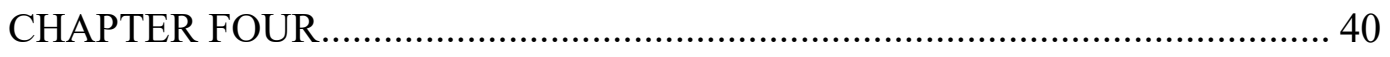

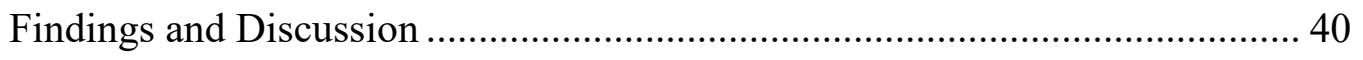

Findings for Fashionpreneur ......................................................... 41

Fashionpreneur Members - Challenges and Opportunities ................... 43

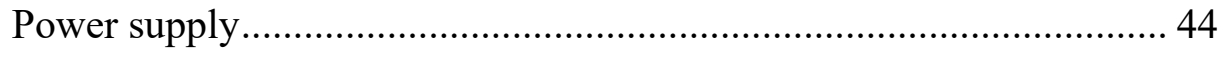

Finances and Infrastructure ...................................................... 45

Resource sharing ....................................................................... 46

Collaboration/Benefits ............................................................ 47

Findings for Non-Fashionpreneurs .................................................. 49

Non-Fashionpreneur Members - Challenges and Opportunities ............ 50

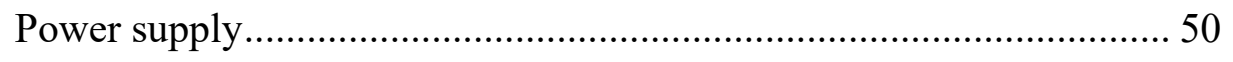

Finances and Infrastructure ................................................... 51

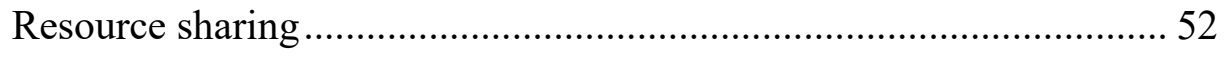




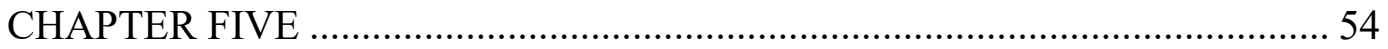

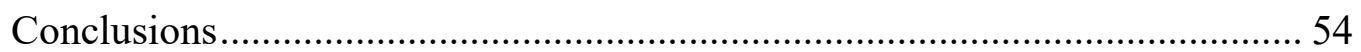

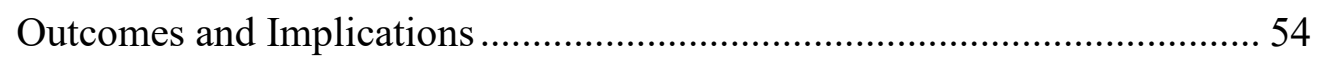

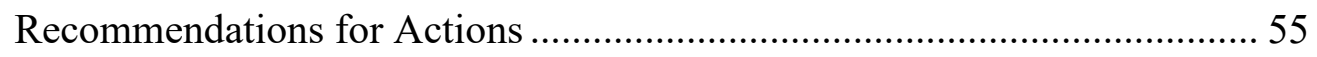

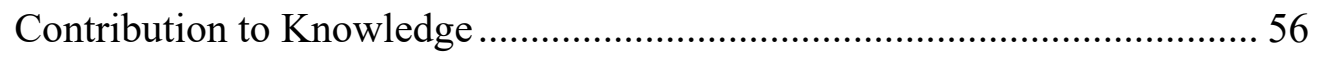

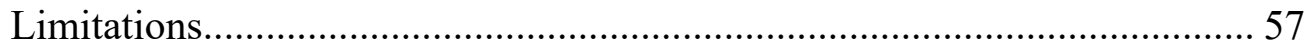

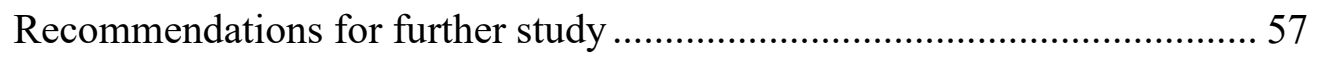

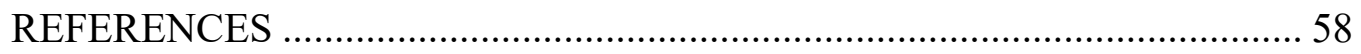

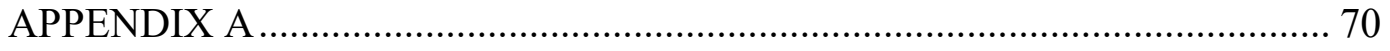

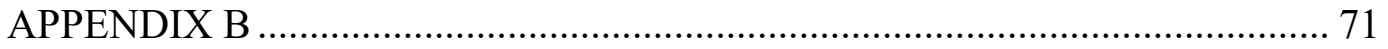




\section{LIST OF TABLES}

Table 1: Characteristics of Fashionpreneurs and Non-Fashionpreneurs ......................... 40

Table 2: Themes and Supporting Responses from Fashionpreneur members ................. 42

Table 3: Themes and Supporting Responses from non-Fashionpreneur members........... 49 


\section{LIST OF FIGURES}

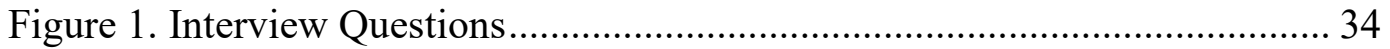




\section{CHAPTER 1}

\section{Introduction}

Entrepreneurship is a vital factor in the development of developing countries, as it enables the economic growth of a nation and boosts sustainable business activity (Parker, 2009). Small business enterprises are central to economic development and constitute a substantial proportion of business enterprises in Nigeria. Small business enterprises are viable means of creating employment, alleviating poverty, and developing indigenous technology at low investment costs (Adisa, Abdulraheem \& Mordi, 2014). Small and Medium Enterprises (SMEs) represent more than 90\% of businesses worldwide and account for more than $50 \%$ of employment and more than half of the world's GDP (Kessey, 2014; Inyang, 2013). SMEs accounts for 97\% of the Nigerian economy and $70 \%$ of these small enterprises employ $82.02 \%$ of the Nigerian labor force $((\mathrm{Shehu}$, Ibrahim, Mat, Nasiru, Popoola, Muhammad, \& Kura, 2013; Adebisi \& Gbegi, 2013; Buowari, 2015; SMEDAN, 2013).

There is an alarming rate of failure in small businesses in Nigeria, which influences the unemployment level, negatively affecting the local and national economy (Ademola \& Michael, 2012; Obiwuru, Okwu, Akpa, \& Nwankwere, 2011). Small enterprise failure in Nigeria has made this sector the final option of employment for several citizens because people participate in small businesses only if there is no other employment opportunity accessible to them (Adisa et al., 2014). Still, $80 \%$ of small businesses in Nigeria failed within the first five years (Adebisi \& Gbegi, 2013; Buowari, 2015). In comparison, $50 \%$ of small businesses in the US fail within the first five years (US Bureau for Labor, n.d.). 
Collaboration is a "process whereby parties who see diverse aspects of a problem can beneficially explore their differences and explore resolutions that exceed their limitations" (Gray, 1989; Guo \& Acar, 2005). Collaboration is beneficial, as it allows the needs and resources to be shared so they can become better entrepreneurs in the marketplace (Bucklin \& Sengupta, 1993). Encouraging a collective spirit in businesses aids the growth of enterprises (Yan \& Sorenson, 2003). Collaborative entrepreneurship is comprised of the formation and application of opportunities made available by linkages with individuals, businesses, and government entities (Naude, Szirmai, \& Guedhuys, 2011). Collaboration for SMEs may be crucial for providing support and resources for these businesses to survive (Dickson \& Weaver, 2011). Collaborative entrepreneurship in this context has to do with resource sharing. These resources can be finances, facilities, knowledge, information, and technology. The main objective of collaborative entrepreneurship is granting access to competencies that aid in meeting the goals and objectives to sustain a business. Advancing the entrepreneurship field is crucial as it identifies ways to help potential entrepreneurs develop their collaborative relationships (Webb, Ireland, \& Ketchen, 2014). This results from collaboration creating a sense of unity in developing countries, as individuals avoid risk but reap the rewards from assisting each other. The Fashionpreneur group is a community of Nigerian fashion designers that uses collaboration for resource sharing for their business growth.

Therefore, it is necessary to explore the challenges and opportunities for these small business communities and explore best practices for their business growth. 


\section{Problem Statement}

The long-term sustainable progress of developing countries originates from their capability to be entrepreneurial and provide solutions to existing business problems by concentrating on collaboration for resource sharing (Ghanem, 2013). Entrepreneurship in developing countries is different from developed countries because of cultural history, government attitudes, and community innovations (Bhardwaj, 2014). This means that research about entrepreneurship in developing countries has followed too closely in the footsteps of the developed world and neglects the crucial role that collaboration plays in developing countries (Ratten, 2014). Collaboration allows a firm to be entrepreneurial and always innovative by exploring new markets. With the reduced success rate of new Nigerian businesses, every advantage and tactic for success needs to be explored to aid small businesses in their development.

\section{Purpose of the study}

This research explores the current challenges, opportunities, and best practices in the collaborative communities of fashion design entrepreneurs in Nigeria. The research conducted in collaborative practices enacted in the education sector, inter-country collaboration, healthcare, technology, supply chain, and business support sectors, challenges, and opportunities in collaborative entrepreneurship has not addressed previous research in the Nigerian fashion industry. Collaborative entrepreneurship is rare in the fashion industry at large. This study is the first study to explore collaborative relationships among small businesses in the Nigerian fashion industry. The analysis used a phenomenological qualitative research approach to explore the current challenges faced 
by these entrepreneurs and gathered their perspectives on collaborative entrepreneurship opportunities.

For these types of projects, it is essential to evaluate challenges faced by small enterprises in Nigeria, and how collaborative partnerships can be used for their competitive advantage. The potential positive social change implications for the implementation of the collaborative business model from this research may include improved economic development, enhanced financial performance, and shared economic value. These advances might lead to an increase in the success rate of small fashion businesses, new opportunities, shared resources, improved living standards, improved employment opportunities, reduction of social mistrust, and upgraded welfare for individuals in the community.

\section{Research Questions}

The research questions for this study are:

R1. What are the challenges faced by fashion designers in Nigeria?

R2. What are the opportunities for collaboration among fashion designers in Nigeria to solve the challenges?

R3. What are the resources required to create a collaborative community for resource sharing among fashion designers in Nigeria?

\section{Objectives}

The objectives of the study are:

i. To identify the challenges and opportunities of the Nigerian Fashion designers.

ii. To explore perceptions of collaborative relationships. 
iii. To examine best practices of a collaborative community of design professionals.

\section{Definition of Terms}

Terms used in this study are defined as follows:

\begin{tabular}{ll}
\hline Entrepreneur & An entrepreneur is an individual who regularly creates and \\
innovates to build something of value around perceived \\
opportunities (Bolton \& Thompson, 2015). \\
The three most leading views regarding entrepreneurship consist of \\
(a) viewing entrepreneurship based on organizational status (e.g., \\
firm size, age or ownership) or the condition of the individual, (b) \\
viewing entrepreneurship based on behavior (i.e., discovery and \\
management of profitable opportunities) and (c) viewing \\
entrepreneurship based on performance (e.g., growth, innovation or \\
social entrepreneurship). While there is no commonly accepted \\
definition of entrepreneurship, a diverse, multi-lens approach, \\
combining the three viewpoints is useful in understanding \\
entrepreneurship. Each gives a clear indication that the field of \\
entrepreneurship is based on a phenomenon that integrates many \\
diverse and heterogeneous features (Audretsch, Kuratko \& Link, \\
2015). \\
An inter-organizational effort to address mutual benefits or \\
common interests among organizations through information \\
exchange process and resource sharing (Tsasis, 2009). \\
Collaboration \\
The creation of something of economic value from a novel jointly \\
created ideas that arise from the sharing of information and \\
knowledge (Franco and Haase, 2013). \\
A creative person whose core entrepreneurial activities are within \\
entrepreneurship fashion, design, or luxury based industries. They usually possess \\
Fashion \\
Entrepreneur \\
a fashion enterprise, venture, or idea and concentrate on results- \\
based creativity. A fashion entrepreneur drives forward the design \\
and fashion industries, expanding their independent sector and \\
representing the best of their local scene. Within the fashion and \\
design industry, a fashion entrepreneur is engaged in the creation of \\
new collaborations and business, co-designed lines/collections, and \\
increased participation at international design festivals to raise \\
recognition of their profile and designs (Ecubator, 2011).
\end{tabular}




\section{CHAPTER 2}

\section{Review of Literature}

Collaboration happens when different stakeholders work together to complete a job and to reach mutual goals. This occurs when two or more individuals or organizations work together for the effective consumption of limited resources. Collaboration encompasses information sharing, market sharing, cost-sharing, improved network design for acquiring raw materials from a supplier, distributing finished products to the consumers, risk-sharing with reduced investment, pressure from stakeholder and government, environmental impact sharing, improved marketing strategies, better managerial behavior, and aspects in terms of social activities (Ray \& Mondal, 2017). Collaboration has been identified by researchers as a significant driver for executing a sustainable business model (González-Benito \& González-Benito, 2005a, b).

One of the most significant factors of business success is the business owner's capability to build a team with skills and talents that match the business owner's qualifications and abilities (Oyeku, Oduyoye, Asikhia, \& Elemo, 2014). The willingness to partner should include collaborations with persons that possess complementary skills. Gupta et al. (2013) added that small business leaders must be flexible and professional to collaborate with other business enterprise leaders successfully. Scholars and practitioners identify the importance of leveraging the variety of thought within an organization to create and execute new ideas. In the present economy of limited resources, organizations recognize the need to do more with less and the need to control inadequate resources for the most significant results (Kelley, 2005).

This study explores the challenges, opportunities, and best practices in collaborative entrepreneurship in small business communities of the fashion industry in 
Nigeria. The study constitutes the general body of knowledge. The review gives a solid background for these terms: collaborative entrepreneurship, creative industries, theoretical frameworks for collaboration, and existing collaborative models.

\section{Creative Industries}

The fashion industry is a subset of the creative industry. Reviewing the creative industry is needed to lay a solid foundation for this study. There are many definitions of "creative industries" and what the creative industries constitute; many of the definitions overlap with "cultural industries" and the "creative economy". The concept largely embraces industries that lie at the intersections of the arts, culture, technology, and businesses that are involved with the production and distribution of creative content. Examples of sectors in the creative industry are fashion design, advertising, architecture, music, art and crafts, the performing arts, television, software publishing, antique market, radio, interactive leisure, design, software, and film (Flew, 2013).

Though discussions about the potential of the creative industries first emerged in Western societies, they have lately spread to the global South, including Africa (Barrowclough and Kozul-Wright, 2008; Mbaye, 2013; Roschenthaler \& Schulz, 2016). In the development debate, awareness of the creative economy has begun to gain momentum, particularly in connection with the belief that economic and cultural developments are not distinct entities and that there is unexploited potential in creative industries. UNCTAD (2010) described the concept of the creative economy as:

"The awareness of the creative economy in the developing world attracts significant creative assets and precious cultural resources that are found in all developing countries. The creative industries that practice these resources not only empower countries to tell their own stories and to project their unique cultural identities to themselves and the world, but they also offer 
these countries with a foundation of economic growth, employment creation, and increased participation in the global economy (UNCTAD (2010, p. 1)".

The question of how well the potential benefits of the creative industry has

materialized in Africa remains mostly unexplored. Though, as Flew (2013) stated, "many important developments in the creative industries are now occurring outside of Europe and North America" (p. vii). Some attention has been shifted to specific creative industries in Africa, such as the film sector in Nigeria (Lobato, 2010) and Burkina Faso (De Turegano, 2008), and the music industries in Ghana (Shipley, 2013), Senegal (Pratt, 2007) and West Africa (Mbaye, 2013, 2015). There is also increasing literature on dress and fashion in Africa (Gott and Loughran, 2010; Hansen, 2013).

This section discusses the big umbrella where the fashion industry generated, which is the creative industry, and the potential benefits embedded in this industry concerning Africa and economic development. This section gives a background in the fashion industry, and this information is for recommending best practices that can improve fashion businesses.

\section{Collaborative entrepreneurship}

Entrepreneurship is an attempt to establish value through recognition of business opportunity, risk management, and the communicative and management skills to organize human, financial and material resources needed to bring a project to fruition (Kao \& Stevenson, 1984). Entrepreneurship is a crucial ingredient in the growth of developing countries, as it enables a country to grow economically and encourages sustainable business activity (Parker, 2009). There are diverse opportunities that exist in developing countries, depending on the product, service, and consumer needs (Ratten, 2014). The three most leading views regarding entrepreneurship consist of (a) viewing 
entrepreneurship based on organizational status (e.g., firm size, age or ownership) or the condition of the individual, (b) viewing entrepreneurship based on behavior (i.e., discovery and management of profitable opportunities) and (c) viewing entrepreneurship based on performance (e.g., growth, innovation or social entrepreneurship). While there is no commonly accepted definition of entrepreneurship, a diverse, multi-lens approach, combining the three viewpoints is useful in understanding entrepreneurship. Each gives a clear indication that the field of entrepreneurship has its foundation on a phenomenon that integrates many diverse and heterogeneous features (Audretsch, Kuratko \& Link, 2015). Entrepreneurship is an attitude exhibited by firms and individuals, which is primarily driven by financial circumstances to solve existing problems in the business environment (Dess, Lumpkin, \& Eisner, 2008). Entrepreneurship involves always discovering, assessing, and taking advantage of new business opportunities (Shane \& Venkataraman, 2000). Communities can be sustained by entrepreneurship by growing businesses and finding a new market and product trends (Franco and Haase, 2013).

Collaborative entrepreneurship is "the creation of something of economic value from a novel, jointly created ideas that arise from the sharing of information and knowledge" (Franco and Haase, 2013, p. 681). This definition focuses on the capability of individuals, businesses, and governments to collaborate to achieve mutually agreed-upon goals in developing countries. The critical aspect of collaborative entrepreneurship in developing countries is about the use of resources in terms of social and economic capital, which can be modified from traditional practices to create additional business opportunities. Sangar and Rangnekar (2014) reported that collaboration in developing countries aims to achieve mutually beneficial results under challenging conditions. The 
likelihood of developing an invention by sharing knowledge is a core feature of collaborative entrepreneurship. Innovation is continuous by broadening knowledge about market potential; collaboration becomes entrepreneurial. This endless innovation supports the concept of collaborative entrepreneurship for creating economic value from ideas sharing that stems out of depositories of information and knowledge (Gupta \& Govindarajan, 2000). A core part of collaborative entrepreneurship is partnerships; business evolves from the management of related resources needed to create economic or social value (Ratten, 2014). Examples of collaboration among African fashion design entrepreneurs are Fashionpreneurs, Let Us Sew (Facebook), Afrikrea (e-commerce platform), Fashionomics (e-commerce platform), and Valisimo group (Facebook). A typical example of collaborative entrepreneurship for the context of this study is the Fashionpreneur group, which consists of 54 members, and the critical activity is resource sharing (knowledge, information, and facilities). This section explains what collaboration is and examples in Nigeria Fashion Industry. This section lays a foundation that there are some benefits attached to collaborative practices.

\section{Theoretical Framework for Collaboration}

Collaborative initiative is a critical factor used by organizations for stability in the face of limited institutional, political, and economic resources. The research on collaboration across disciplines validates that there is no particular model that adequately defines the complex organizational drives for creating informal or formal collaborative relationships (Sowa 2009). Guo and Acar (2005), Sowa (2009), and Proulx, Hager, and Klein (2014) explained collaboration by using multiple theoretical viewpoints - resource dependence, institutional, and network theories to determine variations of collaborative 
initiatives. Resource dependence and institutional theories address the pressures that stimulate collaboration, while network theory characterizes a channel for collaboration.

\section{Resource Dependency Theory}

One of the frequently cited motivations for organizations that attempt collaboration both within and across sectors is the Resource Dependency Theory (RDT) (Bunger 2012; Guo \& Acar 2005; Hillman, Withers \& Collins 2009; Proulx et al., 2014; Weinstein, 2010). Organizations are "constrained and affected by their environment and act to attempt to manage these resource dependencies by setting up different forms of inter-organizational arrangements" (Pfeffer \& Salancik, 2003: xxxiii). RDT concept is a mutual and reciprocal dependence on resources by all organizations.

Age, size, linkages, and budget are presented across the literature as steady factors that fuel the drive for resource dependent collaborations (Guo \& Acar 2005; Sowa 2009). Nevertheless, Sowa (2009) discovered that the main factor that encouraged organizations to collaborate is resource stability, and not size; thus, calling our attention to resource consistency. Although this advocates that smaller organizations with less stability of resources collaborate, the reverse is also true. Proulx et al. (2014) commented that organizations with more resources and better stability have more collaborative relationships. Frequently, the more significant and steadier the collaborative partners are, the fewer the risk they experience to their autonomy. Works of the literature reveal that depending on the different parts of the organizational lifecycle, organizations establish collaborative relationships with diverse motivations; adding value to the relationships is only available at that stage of development. An example of a resource dependency is a collaborative relationship between a male and a female designer in Lagos, Nigeria. The 
male designer specializes in men's wear only while the female specializes in female wears. They both collaborated by sharing resources (finance, facility, and knowledge). The collaboration birthed a male-female collection that got featured at the Nigerian Fashion Show (NFS) week in Abuja, Nigeria.

\section{Institutional Theory}

Institutional Theory speculates that an organization's validity is dependent upon its conformity to the standards and social expectations of the institutional environment (Bunger 2013; Guo \& Acar 2005; Proulx et al., 2014; Sowa, 2009). The U.S. sociologist Zucker (1987) highlighted three essential principles of institutionalization that hold firm today. The first principle is that institutional elements mainly arise from small group organizational level processes. Second, formalized organizational structure and process are likely to be both highly institutionalized and a foundation of new institutionalization. The third principle is that institutionalization improves stability, generating practices that will enhance organizational act except when more resourceful replacements are disregarded. Organizations that pursue collaborative initiatives will not succumb to institutional pressures from either outside sources or within the corporate structure as the lines between standardization and resource control become blurry (Guo \& Acar, 2005). Zucker (1987) found that size, age, and funding similarity are all factors in institutional theory. Guo and Acar (2005) suggest older organizations, that have larger budgets and more board linkages will demonstrate an increased formality in collaborative relationships.

\section{Network Theory}

Network theory suggests that organizations can be inspired to collaborate by a history of collaboration with other organizations (Proulx et al., 2014; Sowa 2009). 
Consequently, the more collaboration, the greater the organization's network. Guo and Acar (2005) submit that organizations with similar board membership and more board linkages have a higher chance of formalized collaborative relationships. Incidentally, older organizations followed suit, with more recognized network influences than their younger counterparts. The main benefit of network-driven collaboration is that the relationship is based on trust (Pittman, 2019).

This section describes the collaboration with multiple theoretical perspectives resource dependence, institutional, and network theories to determine variations of collaborative initiatives. This section gives an understanding of different resources that can be shared by entrepreneurs for their competitive advantage.

\section{Collaboration Models}

Collaboration generally is defined as a 'process whereby parties who see diverse aspects of a problem can beneficially explore their differences and explore resolutions that exceeds their limitations' (Gray, 1989; Guo \& Acar, 2005).

Comparing literature on collaboration across fields is pretty challenging because there is no standard terminology for the different structures of collaborative initiatives. For example, collaboration, partnership, alliance, and integration are usually used interchangeably throughout non-profit literature (Proulx et al., 2014); while definite structures are presented for each term (Berger, Lagarde, Cunningham \& Drumwright, 1999; Kohm, La Piana, D., \& Gowdy, 2000; Seitanidi \& Ryan 2007). Likewise, the collaboration explored on cross-sector in this literature. Management literature refers to these relationships as "non-profit business partnerships," while marketing literature calls 
them "social alliances" (Vock, Van Dolen \& Kolk, 2013). Presented below are the terms and proposed models of collaboration from non-profit management and marketing sectors.

\section{Administrative Coordination}

The administrative coordination model or alliance signifies a treaty between organizations to align support actions such as training, planning and financial management, human resources, or sharing of experts for the benefits of both organizations from services proficiency (Bunger, 2013). Facets of their organizations' infrastructure and processes are linked through shared and exchanged capital, space, and other essential administrative resources for cutting costs and promoting greater productivity. Nevertheless, the participating parties maintain programmatic independence.

\section{Socio-sponsorship}

Sponsorship was the least cited all through literature. Sponsorship is usually viewed from the perspectives of marketing as a basis that aids commercial aims. Though Seitanidi and Ryan (2007) investigate a common way of sponsorship termed 'sociosponsorship.' The authors describe the structure as the channel in which resources are justly assigned from the profit to the non-profit sector, and the company's original resolution is the accomplishment of social responsibility. Also, 'socio-sponsorship' combats the challenges of local communities where they operate. Organization's inspirations for engaging in a collaborative relationship are well-defined in a bid to establish their corporate social responsibility and outline a new bottom line to display the impact of the organization on its constituents. Both parties benefit from the collaborative relationship established. 


\section{Partnership}

Partnership, in contrast, involves a higher level of communication and resources commitment, time, and determination from the parties involved. In this model, substantial partnership characteristics from an inter-organizational view comprise mutual benefit, longevity, and resource commitment or high investment beyond financial resources (Pittman, 2019). The issue with this structure is that non-profit establishments may be viewed as a lower-level partner in such a relationship. Seitanidi and Ryan (2007) comment that for the partnership method to last as an idea and practice, "it needs to contribute to the increase of institutional trust among organizations and across sectors; support in matching the dynamics across the sectors; and appreciate the process of interaction as a source of benefits" (Seitanidi \& Ryan, 2007, p. 247).

\section{Strategic Alliance}

This review has predominately focused on alliances. A 'strategic alliance' is said to a close, mutually beneficial, lasting partnership intended to achieve strategic goals for both partners, which include resource sharing, information, and abilities (Berger et al., 2004). Kohm et al. (2009), a deliberate reformation that embraces an obligation to stay true to the predictable future transferred or shared policymaking power, and some formal treaty (managerial consolidation and combined partnerships).

\section{Social Alliance}

"Social alliance" is used when an alliance is above the boundary span of the nonprofit/ for-profit boundary (Berger et al., 2004; Weinstein 2010). "Social alliances are distinguished from strategic alliances by two main characteristics. First, they involve at least one non-profit partner. Second, in addition to traditional economic objectives, social 
alliances include 'non-economic' objectives, based on resource exchange of both tangible and intangible assets" (Berger et al., 2004, p. 59). Berger et al. (2004) disclose that social alliance may be different in each sector. Social alliances for businesses can characterize a merging of corporate policy and social responsibility. Access is granted to resources that are beyond cash involvement to contain supervisory advice, technological and communications support, and a trained volunteer force for non-profits. Berger et al. (2004) state that there is no single way - or even the best way that social alliances are organized. Instead, the social alliance model can be "designed, structured, nurtured, and maintained in a manner that will enable both [parties] to contribute to solving pressing social problems and to fulfilling important strategic objectives" (Berger et al., 2004, p. 88).

\section{Integrations}

In representing the farthest end of the field of collaboration, integrations must not be overlooked. These are associations that include adaptations to organizational control and/ or structure as well as the possibility for the formation or disbanding of participating organizations or a merger of the two (Proulx et al., 2014; Kohm et al., 2009). This form of association is opposing widely held research that has presented collaboration as the allencompassing term to define a multitude of tactics and structures like partnership, sponsorship, along with social and strategic alliances. Collaboration, as introduced by Kohm et al. (2000) and Proulx et al. (2014), is a classification in which alliances and integrations are ranked in three distinct strategies in order of diminishing autonomy and growing formality. This submission, thus, narrowed the vital metrics for equating relationships to the collaboration's formality degree. 
Regardless of the absence of standard terminology across literature, researchers present a wide range of relationships that begin in the stage of information sharing. Then into joint management, into more integrative structures, demanding valuable time and resources from both the participating partners for their mutual benefit. Guo and Acar (2005) highlighted definitions of the choice of formality that expresses informal collaborative relationships as one whereby there is no ongoing commitment by participating establishments to the partnership and decision-making power over crucial supervision functions stays with the individual organization. The reverse is the case for a formal collaborative relationship (Guo \& Acar, 2005; Kohm et al., 2000). There is a greater loss of independence in this type of collaborator model (Guo \& Acar, 2005). This section lays the foundation of the roles partners play during collaborative relationships. A collaborative relationship is successful when the parties involved keep to their roles. For the purpose of this study, parties that will collaborate must be ready to share their unique resources with other partners.

These collaboration models described above are to clarify the different terms and definitions used for collaboration. This section explores different perceptions of collaborations and their implementation. Best practices will be suggested using some of the concepts shared in these collaboration models.

\section{Themes Common Across Research in Collaboration Models}

Regardless of the various collaboration models highlighted, very few themes are cited as vital indicators of success generally across fields and disciplines. The core themes are appropriate partner fit (Berger et al., 2004; Stevens, 2008; Austin \& Seitanidi, 2012; Vock et al., 2013); alignment around common goals (Tsasis, 2009); balance within 
the power dynamic between members; and trust (Bunger, 2013; Seitanidi \& Ryan, 2007; Tsasis, 2009; Vangen \& Huxham, 2003; and Cornforth et al., 2015).

\section{Partner Fit}

One of the first steps in collaborating is finding an appropriate collaborative partner. Nine measures of fit, when addressed, can prevent common problems in a collaborative partnership. These are mission fit, resource fit, management fit, workforce fit; target market fit; product/cause fit organizational culture fit, lifecycle fit, and fit accompanied by an evaluation of success by the organization (Berger et al., 2004). Additional research submits that the more critical factors are mission fit (Austin \& Seitanidi, 2012), management fit, resource fit, and evaluation fit. These factors must be present from the early stages of the relationship because they develop slowly and also challenging to change (Berger et al., 2004). A low power dynamic, misalignment of partnership goals, mistrust, and diverse definitions of success address fit problems. There should be clear communication among partners to clarify their intents and the roles each party will assume in reaching the collaborative goals - developing communication between partners and endorsing a more balanced structure between affiliates. There is an increase in the potential of positive co-creation of executive capacity and the environmental and economic value for partners in a collaborative partnership with high measures of fit all over the stages (Austin \& Seitanidi, 2012).

\section{Trust}

In driving value co-creation, trust is considered as the foundation of productive collaborative relationships (Bunger, 2012; Seitanidi \& Ryan, 2007; and Tsasis, 2009). Although trust is perceived as necessary in overall business relationships and business/ 
non-profit collaborative partnerships, it was proposed by Seitanidi and Ryan (2007) that there is no alignment of trust across divisions. The authors advise that business views on trust exist in the concepts of risk reduction, while the social contract view of trust is perceived among partners of non-profit organizations (Seitanidi \& Ryan, 2007). Tsasis (2009) further investigates the benefits of interpersonal trust between the partnering establishments, as interpersonal relations have more extensive influence and interorganizational trust. Nature and social bond quality concerning dependability and trustworthiness, within the collaboration framework, is likely to bet as essential as the economic and institutional inspirations for collaboration (Bunger, 2013). Trust is expected to be the alleviator against danger and opposition and cannot be established without other vital variables (Vangen \& Huxham, 2003). Time and cautious deliberation on other fundamental problems similar to the measures of fit are needed in building trust (Berger et al., 2004).

In contrast, researchers disagree on the establishment of trust. Some researchers, viewing from board connections perspectives, believe that trust is the foundation on which collaboration is built. In contrast, others suggest that trust is established all through the collaboration process (Vangen \& Huxham, 2003). Vangen and Huxham (2003) introduced a concept called 'trust-building loop'; the loop defines the process as any time result meets expectations, trusting attitudes are bolstered. The result is part of the history of the affiliation, and this increases the likelihood of positive expectations from partners about combined activities in the future. Vangen and Huxham (2003) resolved that the 'trust-building loop' presents a robust case for entering collaborative associations through simple, minimum risk action, i.e., trust-building via successful results. Vangen and 
Huxham (2003), however, address the situation that not every collaborative relation lasts long enough to gain the full potential value of the partnerships. They stated that "the collaborative advantage requires the members to adopt higher-risk initiatives to experience the value of the relationship more quickly.” (Huxham, 2003, p. 16)

\section{Value}

Successful collaboration is fundamentally beneficial to the individual partners involved and can have a long-lasting impact outside the partnership in the broader community. Austin and Seitanidi (2012) highlight a value formation scheme that describes four kinds of value formed during collaborations: associated value, transferred value, interactive value, and synergistic value. The associated value is experienced by associates via higher visibility and reliability; improved public attention and backing; and increased positioning that leads to better loyalty degree from existing and new participants. Advancement of other palpable resources like funding and communal capital comes from the transferred value of the affiliation. Also, the interactive value gained from high partner fit creates opportunities to enlarge competences and proficiency gathered from more extensive networks. Finally, the synergistic value present in collaborative associations signifies a broader influence supporting leadership and power in the area and society as establishments start to concentrate on the "triple bottom line" of people, the planet and profitability, and seek actions that create corporate social responsibility (Stern, 2015).

Noticeably from the examples above, establishments employ collaborative approaches that generate more significant influence, creating value that goes beyond their 
missions owing to resources shared and forged linkages. Thus, these vital indicators (themes) will help create a thriving collaborative community of fashion entrepreneurs.

\section{Fashion Design in Nigeria}

Nigeria is blessed with natural and cultural resources. The nation's natural resources are comprised of crude oil, gas, and marine life, agriculture, forestry, and allied products, minerals, and metal ores (Ekpe \& Nnochiri, 2009). Furthermore, its rich cultural heritage includes traditions, languages, oral history, folklife, religious ceremonies, customs, and traditional creative skills like arts, crafts, and performances. Amongst the local arts and crafts of the Nigerians are textiles and fashions that have been with them and passed from generation to generation. Textile and clothing thrived in Nigeria as early as the ninth century A.D (Afigbo \& Okeke, 1985). The visual cultural expressions shown among Nigerians is the same for other African cultures. Also, because of its performance and daily usage, the textile is one of the most apparent cultural products among Nigeria's numerous cultures. Shea (in Emeagwali, 1992) examines that a tourist to Nigeria is usually firstly impressed by the textiles. The vast varieties, beauty grandiosity, colors, textures, elegance, and style are all instantaneously stunning. Males and females occasionally store an impressive amount of textiles as well as finished clothing. It is not strange for Nigerians to have clothes that belonged to their grandparents or older generations. This national desire for gorgeous textiles and clothing is the outcome of many centuries of growth and of significant investment in time, energy, enterprise, ingenuity, and capital. Shea (1992), concerning this, assumes that one of the most specialized activities in Nigeria is cloth making. If properly exploited, developed, and marketed to local and global audiences, these specialized textile and fashion-related 
activities can thus transform into job creation, poverty alleviation, international trade, and ultimately economic growth (Ekpe \& Nnochiri, 2009).

African fashion has inspired and has been inspired by other cultures. Post renaissance Europe greatly admired the raffia of central Africa, and it found its way into European treasuries along with other inventions of African arts. According to Meller (1996), African fashion styles evolved from a blend of African and western cultures. African designers produce clothes of western designs using traditional African textiles. Consequently, one sees kente (Ghana print textile) ties and coats, adire (Nigerian textile) suits, Aso-oke (Nigerian textile) skirts, and blouses, etc. Presently, traditional African fashion styles are designed using a combination of western and African cloth. Hence, one might see a traditional Nigerian dress made from western designed cloth with an accent of African cowries, raffia, adire, and other motifs. African dress influences fashion all over the world. In October 2017, renowned British fashion designer Stella McCartney launched her Spring 2018 collection at Paris Fashion Week. Her (mostly) white models swayed down the runway clothed in magnificently colorful, sheeny Ankara fabric, the traditional cloth associated with West Africa (Old traditions, 2018, Nov 29).

\section{Nigerian Fashion Market}

Africa, in general, and particularly Nigeria, is blessed with a rich diversity of indigenous cultures, and this is obvious in Nigerian fashion (Ekpe \& Nnochiri, 2009). Consequently, M. Bawa (personal communication, May 31, 2000) validates there is a sizeable modern-day market for African fashion. The state-level acknowledged the importance of the industry, as when the Tunisian Embassy embarked on a joint mission to promote African culture and fashion as an economic development project. According 
to the African Development Bank, request for African fashion is increasing globally, and African patterns are fast acquiring international recognition. Fashion houses now integrate more African inspirations, fashionable and iconic pieces, with international design in their latest collections. As President Zewde stated: “Globally, Africa's cultural colors and clothing are increasingly accepted (African union: Fashionomics Africa supports launch of pan-African fashion initiative, 2019, Feb 21).

Growing the Nigerian economy is essential to providing employment opportunities and ensuring that residents in every part of the country have a good quality of life. Africa's informal sector is of crucial importance. Most working women are selfemployed and own-account workers in this sector, suggesting an access point for increased participation in the private sector. Women entrepreneurship has positive implications for national development and economic growth (Bardasi, Blackden, \& Guzman, 2007). When a business is set up and controlled by a woman, it boosts not only economic growth but also has many advantageous outcomes (Sharma, Dua, \& Hatwal, 2012). Entrepreneurship and women entrepreneurship, specifically, is critical to the economy of a nation for economic development and poverty reduction (Ekpe, 2011). The government of a country is obligated to provide an empowering environment for entrepreneurship development in terms of promising financial, economic, socio-cultural, legal policies, and functional infrastructure (Ekpe, 2011; Coleman \& Kofi, 2008).

Women entrepreneurs make a significant impact on national economies through their contribution to start-ups and their growth in small and medium businesses (United Nations, 2006). Their interests and activities in economic growth and development, particularly in SMEs, are of interest to researchers. Therefore, women are becoming 
increasingly important in the socio-economic development of both developed and developing countries as they account for a significant percentage of the operators of Small and Medium Enterprises (SMEs) (Josiane, 1998; Kjeldsen and Nielson, 2000).

Regardless of the challenges the industry is facing, Nigerian-inspired fashion is taking the streets and the world by storm. Edwards (2000) and Ankoma (1998) concur that when one walks the streets of New York, Paris, and London, possibilities are that one will see some people dressed in the Nigerian and African-inspired outfits. Among African Americans, especially, wearing so-called "authentic" African attire has become a fashion statement. The African Diaspora has embraced African fashion the world over (Ekpe \& Nnochiri, 2009).

Since Nigerian indigenous textiles have become viable locally and globally, developing the textile and fashion industry in the country could have positive impacts such as launching the establishment of quality, authentic Nigerian brands to compete with international players. Hence, fashion in Nigeria should aim to collaborate with other African countries in displaying, promoting, and developing African fashion, especially traditional African designs (Ekpe \& Nnochiri, 2009). Additionally, it should incorporate diverse facets of culture, creating a platform for cross-cultural collaboration allowing Africans to share in the other rich cultures of the African continent. The most significant aim is to encourage the economic growth of individuals through local and international trade in the dynamic textile and fashion industry. Nigeria is undeniably a nation with enormous potential in terms of the natural, cultural, and human resources that exist all over the country. If these resources can be sustainably engaged, there is no doubt that 
Nigeria will prosper. Therefore, there is a need to explore ways to maximize these resources through collaborative entrepreneurship.

In this literature review, different collaborative models were used in various collaborative partnerships because of the participating members. Collaborative models are employed based on some underlying factors, such as age and budgets, for needs to be met. Progressively, it will be significant to identify the double pressure of collaboration and competition in the contest for resources, which stands as the main barrier for some establishments to enter collaborative relationships despite the need (Bunger 2013; Proulx et al., 2014).

Entrepreneurship is a great empowerment tool, especially women entrepreneurship, which is critical to the economy of a nation for economic development and poverty reduction. Since women dominate the fashion design industry, this industry has the potential to develop the economy; consequently, the need for this study. Therefore, this research has the potential to recommend best practices to create a successful collaborative relationship and how collaborative partnerships can be used for their competitive advantage to this population. 


\section{CHAPTER 3}

\section{Methodology}

\section{Purpose of the study}

The purpose of this study is to explore the challenges, opportunities, and best practices in the collaborative communities of fashion design entrepreneurs in Nigeria. For these types of projects, it is essential to evaluate challenges faced by small enterprises in Nigeria, and how collaborative partnerships can be used for their competitive advantage. The positive social change implications for the implementation of the collaborative enterpreneurship suggestions from this research may include improved economic development, enhanced financial performance, and shared economic value. These advances might lead to an increase in the success rate of small fashion businesses, new opportunities, shared resources, improved living standards, improved employment opportunities, reduction of social mistrust, and upgraded welfare for individuals in the community.

\section{Objectives}

The objectives of the study are

i. to identify the challenges and opportunities of the Nigerian Fashion designers,

ii. to explore perceptions of collaborative relationships, and

iii. to examine best practices of a collaborative community of design professionals.

\section{Research Method and Design}

For the analysis of this research, I used an inductive qualitative research approach to explore the current challenges faced by Nigerian fashion small business entrepreneurs 
and to gather their perspective regarding collaborative entrepreneurship. Barnham (2012) claimed that the qualitative research method simplifies the study of human social problems in-depth. Qualitative research provides an understanding of the participant's views and experiences (Montero-Marin, Carrasco, Roca, Serrano-Blanco, Gili, Mayoral, \& Garcia-Campayo, 2013). The qualitative method is the best method that meets the needs of this study which explores best practices used by these designers to provide a competitive advantage for small businesses. A pilot test was conducted with two entrepreneurs with two qualitative interviews to test the instrument. The research instrument yielded the desired information to provide more specific information.

For this study to meet its objective, I chose a qualitative phenomenological design. A phenomenological design involves the exploration of peoples' experiences and their opinions and developing these experiences into a real-life model (Stierand \& Dorfler, 2010). A phenomenological study is an exploration of how entities' lived experiences expose themselves to others (Ilkay, 2013), and permits the researcher to comprehend participants' views and gather information on their experiences (Ginsberg \& Sinacore, 2013). Phenomenological studies involve open-ended questions for participants to explain their lived experiences (Ginsberg \& Sinacore, 2013).

For this study, the phenomenological design is vital in exploring the challenges and opportunities examining best practices of a collaborative community of design professionals. The lived experience that focused on the personal stories of these entrepreneurs is invaluable. This experience explored how entrepreneurs are coping with their challenges. Their stories revealed how each entrepreneur uniquely manages and pulls through their businesses in the face of challenges. Also, with preserved 
individuality, there may be similarities between them that develop into themes generated from the interview like power supply, capital/infrastructures, resource sharing and collaboration/benefits.

\section{Bracketed Researcher Notions}

Bracketing was used in the research methodology of this study. To address my own biases that arose in the interviews and analysis, I employed bracketing, which meant suspending my own biases and empathizing with the study participants' perspectives. I bracketed my biases by making them blatant and frequently scrutinized how my knowledge might be meddling with arriving at an empathetic connection with the participants (Creswell, 2009). Though my bias was not entirely out of the way, the process of bracketing enabled me to cognitively investigate new knowledge gathered from participants and my previously held experience. Bracketing my notions was essential to admit my impact and bias before, during, and after data collection. This act recognized the relationship between my positioning, experiences, and the information taken.

I have had an interest in the unique experiences and needs of African fashion designers since I was in high school. As a native Nigerian, I have been exposed to entrepreneurship since I was in high school. As an assistant in my mum's graphic design business, I noticed the struggles she went through in sustaining the business. It later closed due to mismanagement by the staff. My mother could not salvage the situation because she had limited business organizational knowledge. If she had partnered with other business owners who had excellent management skills, her business might not have failed. 
My first introduction to Nigerian Fashion occurred after my high school graduation when I was enrolled as an apprentice in a fashion design workshop with Madam Dele. There, I learned the basics of African fashion design techniques, cutting, and sewing, all within 24 months. After this apprenticeship experience, I desperately wanted to not only establish a fashion design workshop but also look for best practices to sustain my fashion business. In the quest for this knowledge, I stumbled upon the opportunities in collaborating for the sake of sharing resources. Following this quest for helping Nigerian fashion designers, I decided to focus my research on the challenges and opportunities in collaborative entrepreneurship. Given the alarming rate of business failure in Nigeria, I am concerned about the best practices for business sustainability. As many of my experiences and perspectives developed in my hometown of Lagos, Nigeria, my study explores the aspects of Nigeran fashion entrepreneurship. Therefore, I hope to understand more about the challenges faced by these entrepreneurs and hopefully gain insight into how I can aid in business sustainability by presenting best practices.

Identifying as a Nigerian fashion entrepreneur and still being connected to the community, I believe I will be able to connect and relate to the participants on a personal level. There may be some shared experiences and understanding that I could hold with the participants that may be advantageous to the entire process.

\section{Population and Participant Recruitment}

An important part of the methodology for this research was interviews with two groups of people: Fashionpreneur members and non-Fashionpreneurs members. Although the participants have similar experiences, each participant's responses were analyzed separately. This analysis technique allowed for an overview of all participants' responses 
to be compared against each other to gain an understanding of each member's experience in their best practices for sustaining their businesses.

Oluwaseyi Adegoke Awalade founded the Fashionpreneur Group on Feb $1^{\text {st }}$, 2018. Adegoke saw the challenges faced by Nigerian fashion designers and decided to create a social media platform for information sharing for their business growth. The group has a nine-member committee that oversees events. Some of the events are for networking, self-development, and business growth training. The business is also involved in some collaborative practices like infrastructure sharing, resource sharing, and cost-sharing. There is no registration fee for joining the group, but members must be involved in at least one collaborative practice. The common collaborative practice everyone is involved in is the daily contribution of 1,000 Naira (or approximately three US dollars). The contribution is paid weekly on Friday as a sum 5,000 Naira (or about fourteen US dollars) into a bank account. The members collected this daily contribution in turn, according to their chosen number. The contribution aims to help the members buy equipment needed for business operations they are yet to acquire. The Fashionpreneur committee will have access to the result of this study. The result will recommend best practices in creating a successful collaborative relationship and how collaborative partnerships can be used for the designer's competitive advantage.

Purposive sampling, which is a non-probability sample that involves identifying and selecting individuals or groups of individuals that are particularly knowledgeable about or experienced with a phenomenon of interest (Cresswell \& Plano Clark, 2011), was used for this study. This sampling method ensured that the participants had experienced the phenomena (best practices in sustaining their business) and could 
provide rich information about their experiences with that phenomenon (Merriam, 2009). As a requirement for participation in this study, fashion designers selected for the study were: (1) practicing fashion designers in Nigeria and (2) had been in business for at least two years. There was a total of seven Fashionpreneur members (three females and four males) and four non-Fashionpreneur members (three females and one male) and a total of 11 semi-structured interviews.

Twenty invites were sent individually to the Fashionpreneur members. Fifteen out of them responded, but seven out of the participants scheduled time for the interview. In recruiting Fashionpreneur members, I shared the details about the research on the group's social media platform, and messages were sent to twenty group members randomly. For the non-members, I reached out to my fashion designer friends in four separate locations in Lagos state to participate, and they agreed. Participants' convenience was a priority when scheduling the interview. There was no incentive given to the participants for participation. A summary of the research and benefits was explained to the participants before the interview. The IRB protocol number is \#2001878476, with exemption status. In qualitative research, the number of participants selected is based upon the availability and range of participants to choose who experienced the phenomenon; data saturation or data redundancy may be determined after the study has begun (Seidman, 2013).

Since experts consider that researcher themselves are important data collection and analysis instruments (Condie, 2012; Sarker, Xiao, \& Beaulieu, 2013), I was always aware of my own role as the principal data gathering instrument. I applied sensitivity, and employed knowledge and expertise so that I could produce quality data (Rowley, 2012). The purpose of this study was to explore the best practices in the collaborative 
communities of fashion design entrepreneurs in Nigeria. I followed an interview protocol for this research and asked all the participants the same questions for ensuring validity and reliability. Participants were permitted to evaluate the information collected to establish data accuracy, which is vital to the investigator and identified as a transcript review (Singh, 2011). I ensured that the participant's responses were well captured through member checking by verifying their responses at the end of the interview. Member checking is a method of establishing the accuracy of a report or a justification for a condition (Harper \& Cole, 2012). Member checking means repeating the information and requesting the participant to confirm its accuracy and the meaning of the words (Harper \& Cole, 2012). The interview protocol consisted of opened-ended questions that brought a deeper understanding of the challenges faced and the resources needed for entrepreneurs to succeed. The protocol allowed participants autonomy and flexibility during the process of the interview.

This study employed semi-structured interviews. They contained open-ended questions to offer guidance consistently and systematically, with extra analytical techniques that made discussions focused and fruitful, which led to a detailed and comprehensive data (Rubin \& Rubin, 2012). The usefulness of the instrument was enhanced by presenting the interview questions to experts for their opinions and validations, as suggested by Ekekwe (2013). Analytical questions were asked to get a deeper understanding of participants' challenges and recommendations. As the interview unfolded, probing questions were asked for the purpose of clarity.

At the beginning of this study, I had anticipated conducting at least fifteen 
interviews, ten (10) from the Fashionpreneur group members, and five (5) from the nonFashionpreneur members. However, because of time, schedules, and time zone differences, only twelve (12) interviews were carried out. The interviews were conducted via WhatsApp voice call, rather than in person. 


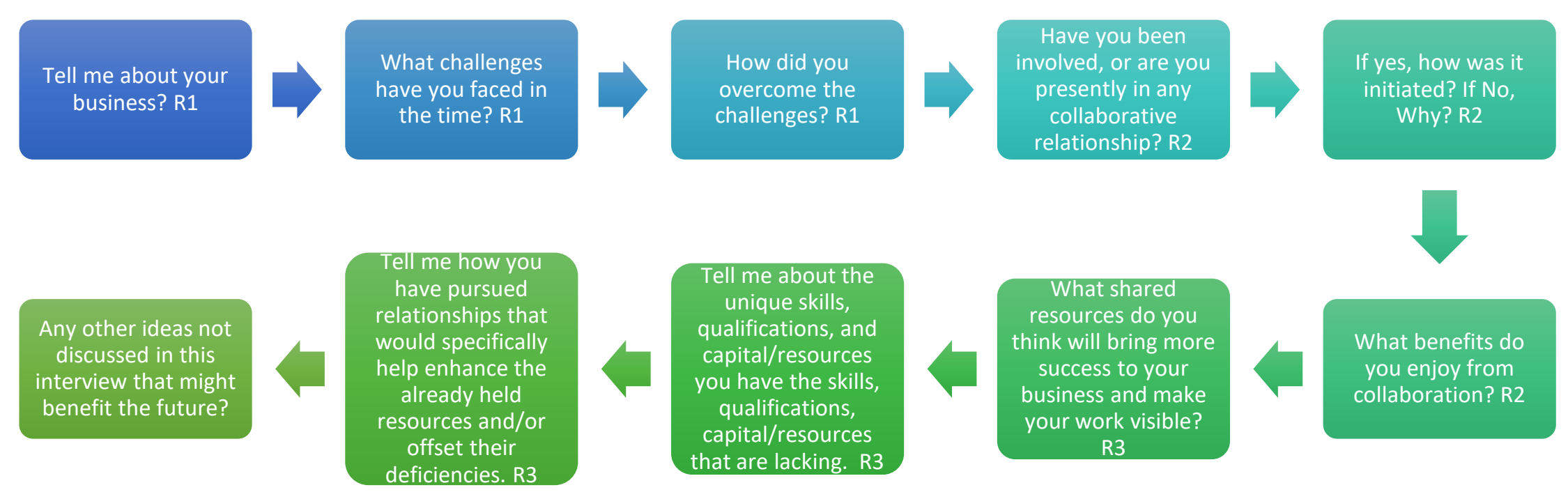

Figure 1. Interview Questions 


\section{Data Collection and Analysis}

The purpose of using the interview to collect data for this study was to explore the participant's lived experiences and participants' views about the research topic (Anugwom, 2011; Moustakas, 1994). An interview is a discussion between the research participant and the investigator for responding to the research question (Onwuegbuzie \& Byers, 2014). The interview was scheduled at a convenient time, and the data was captured using a recording device. To obtain correct data, the researcher must keep prejudice away and have an open mind (Kim, 2011). In-depth interviews through member checking are essential in satisfying the objective of qualitative phenomenological research (Marshall, Cardon, Poddar, \& Fontenot, 2013). Data saturation is realized when there is sufficient information to duplicate the study (Mason, 2010), additional information becomes extraneous since no new themes arise, and further coding is no longer needed (Guest, Bunce, \& Johnson, 2006).

Researchers employ member checking to enhance the accuracy, credibility, and verifiability of data collected and analyzed all through research (Harper \& Cole, 2012). I verified the answers to the interview questions after the interview was over to ensure member checking.

\section{Instrumentation}

A semi-structured phone interview was conducted to gain information about the participants' best practices. The interview questions and process were the same for both groups. At the very beginning of the interview, the participants were asked a series of question on business information (i.e., business name, business start date, expertise, and 
business size), followed by their participation in a semi-structured and opened-ended interview that their challenges and opportunities of their business.

Phenomenological interviews were created based on Seidman's (2013) Three Interview Series, which employs structured separate sections of interviewing that allows for both parties to explore the participant's experience, place it in context, and reflect on its meaning. The interview sections were written down first to reconstruct their business experiences with a phenomenon, then reflect on those experiences with current exposure to the phenomenon, and end with a final section revealing meaning and further understanding of their business concerning the phenomenon (Siedman, 2013). The participants were interviewed with all three interview sections, pausing between each one to allow reflection. The interview was structured as follows:

- What are the challenges faced by fashion designers in Nigeria?

- What are the opportunities for collaboration among fashion designers in Nigeria to solve the challenges?

- What are the resources required to create a collaborative community for resource sharing among fashion designers in Nigeria?

The interview was scheduled at the participant's convenient time. I asked some probing questions for more knowledge elicitation. The phone call interviews ranged from 20 to 30 minutes.

\section{Data Analysis}

All interviews were transcribed verbatim and reviewed to ensure accurate transcription. I listened to the recordings and wrote down the answers verbatim, and also noted the emergent themes. Following transcription of all interviews, this study employed 
thematic analysis. This process was selected because it supports phenomenological qualitative research (Merriam, 2009; Seidman, 2006) to richly and openly explore the best practices of these designers. Through detailed, thick descriptions gathered from direct quotations from participants, responses led to significant themes that emerged throughout the study. Data were analyzed using the thematic analysis procedures listening to the recording of the interview, assigning equal value to highlight and reduce significant statement.

Upon the completion of the interviews, the interviews were transcribed into Word documents. Each transcript was written down, read multiple times using the categories of challenges and opportunities, perceptions of collaborative relationships, and best practices collaborative entrepreneurship to keep the information together and to be concise so the participant's responses would not become tangled. The transcripts were then reread, highlighting, and noting significant or similar phrases, concepts, words, or descriptions in the transcriptions. Within the interviews, keywords and phrases emerged, showing developing themes and commonalities. Throughout this section, blockquotes are used for the interviews so the reader will be able to get the full, immediate, and pertinent quotes, without the researcher skewing the meaning by paraphrasing. The findings from this research were presented for member checking by reconfirming the participants' answers after the interview to confirm the transcripts.

\section{Reliability}

The trustworthiness of qualitative research findings originates from the dependability and credibility of qualitative research (Munn, Porritt, Lockwood, Aromataris \& Pearson, 2014). I conducted a pilot test to ensure that the data collecting 
instrument was producing useable and insightful data. The pilot test was conducted first by practicing the interviewing techniques, testing the recording instrument, and interview questions before the significant study interviews are conducted. I refined the interview questions after reviewing the data gathered. The pilot audience consisted of one Fashionpreneur group member and one non Fashionpreneur member. I transcribed verbatim the audio recording of each interview to certify that the opinions and views expressed during the discussion were precisely captured (Kornbluh, 2015). Participants were engaged in member checking as recommended by research experts to boost the trustworthiness of the information and the dependability of the results of qualitative studies (Eno \& Dammak, 2014). I ensured reliability for the interview process.

\section{Validity}

Validity in a research study concentrates on effectiveness as well as rigor and authenticity (Merriam, 2009). To enhance validity in this study, epoché, also known as bracketing, was utilized to avoid the researcher making personal judgments that influence the authenticity of the findings and increase bias that weaken the voices of the participants. Member checking during the interview was employed to boost validity. This system requires the researcher to follow-up during and following the interview to ensure the participants verify the report. Also, recording and transcribing interviews verbatim increased validity. The three-part series of interviews also enhanced validity by allowing participants the chance to progressively build on their knowledge of the phenomena and verify the internal consistency of what they shared in their interview (Seidman, 2006).

Some detailed and thick descriptions provided experiences of fashion design entrepreneurs in collaborative practices to enhance the transferability of findings. Also, 
maximum variation was employed to widen the application of the results to a broader audience (Merriam, 2009). To maximize variety, participant selection was opened to seven (7) Fashionpreneur members, and five (5) non-Fashionpreneur members and their businesses have been in existence for over two (2) years.

Phenomenological research centers on explaining the real meaning of the participants' stories and experiences. To avoid any of the researcher's biases or experiences from influencing the data, the author's own experiences correlated to the population, and the subject matter will be investigated (Merriam, 2009). Phenomenology aims to emphasize the participants' experiences in a clear and inspiring way instead of proving theories or research right or wrong. This study aims to explore collaborative relationships and recommend the best practices needed for successful collaborative entrepreneurship to inform future research and intervention.

\section{Use of Findings}

The results of this research recommended best practices in creating a successful collaborative relationship and how collaborative partnerships can be used for the designer's competitive advantage. If Nigerian fashion designers implement these findings, they might improve their business outcomes and advance in the marketplace. The aim is that these advances might lead to an increase in the success rate of small businesses, new opportunities, shared resources, improved living standards, and improved employment opportunities, reduction of social mistrust, and upgraded welfare for individuals in the community. The results of this research was presented to the committee of the Fashionpreneur group and inform future research and intervention. 


\section{CHAPTER FOUR}

\section{Findings and Discussion}

This chapter describes the data gathered from the interviews in this study. The description of the designer's experiences will provide further understanding and context into the challenges, opportunities, and best practices so far. Following this section will be a description of the significant findings gathered guided by research questions

The participants in the research were seven practicing fashion designers in the Fashionpreneur group and five non-Fashionpreneur group members in Lagos, Nigeria. The participants were fashion entrepreneurs that are more than two years in business. Participants were obtained from a purposeful sampling effect and through the membership lists of the Fashionpreneur member and non-members. Many of them had experience in benefits, opportunities, and challenges in their business, thus contributed to their knowledge of collaborative entrepreneurship drawing upon their field of expertise. The Fashionpreneur participants, who were males and females, will be referred to as Ade, Ola, Lara, Yemi, Odun, Aduke, Dare, and non-members as Ore, Toyin, Akin, and Taiwo for the protection of their information. In general, each of the participants had been in operation for over two years. See Table 1 for a highlight of some of the participant's characteristics.

Table 1: Characteristics of Fashionpreneurs and Non-Fashionpreneurs

\begin{tabular}{llll}
\hline Participant & Expertise & $\begin{array}{l}\text { \# of Years in } \\
\text { Business }\end{array}$ & $\begin{array}{l}\text { Size of the } \\
\text { Business }\end{array}$ \\
\hline Ade & $\begin{array}{l}\text { Men's \& Women's traditional, native } \\
\text { wears, Custom-made and Ready to }\end{array}$ & 2 \\
& $\begin{array}{l}\text { wear } \\
\text { Ola }\end{array}$ & $\begin{array}{l}\text { Men's wears, corporate \& native } 11 \\
\text { wears, Custom-made and Ready to } \\
\text { wear }\end{array}$ & \\
\end{tabular}




\begin{tabular}{lll}
\hline Lara & $\begin{array}{l}\text { Men's wears, corporate \& native } \\
\text { wears, Styling, Branding, Bespoke, } \\
\text { Wardrobe consultation, Styling, }\end{array}$ & 6 \\
& $\begin{array}{l}\text { Footwears, Custom-made and Ready to } \\
\text { wear }\end{array}$ & \\
Yemi & $\begin{array}{l}\text { Women's wears, beadwork \& couture, 5 } \\
\text { bridals, Custom-made }\end{array}$ & 4 \\
Odun & $\begin{array}{l}\text { Men's wears, native wears, Ready to } 3.5 \\
\text { wear }\end{array}$ & 4 \\
Aduke & $\begin{array}{l}\text { Women's wears, corporate \& native } \\
\text { outfits, Custom-made and Ready to } \\
\text { wear }\end{array}$ & 2 \\
Dare & $\begin{array}{l}\text { Fashion branding, Custom-made } \\
\text { Ore }\end{array}$ & $\begin{array}{l}\text { Men's \& Women's wears, corporate \& 3 } \\
\text { native outfits, bridals, Custom-made } \\
\text { and Ready to wear }\end{array}$ \\
Toyin & $\begin{array}{l}\text { Women's wears, corporate \& native } \\
\text { outfits, bridals, Custom-made } \\
\text { Women's wears, native outfits, 3 } \\
\text { Akin }\end{array}$ & 4 \\
Taiwo & $\begin{array}{l}\text { Men's wears, Custom-made and Ready } \\
\text { to wear }\end{array}$ & 4 \\
\hline
\end{tabular}

\section{Findings for Fashionpreneur}

From these categories of challenges and opportunities, perceptions of collaborative relationships, and best practices collaborative entrepreneurship, there were several main themes generated across the interviews; Power supply, Finances and Infrastructure, Access to fabrics, Government support, Market Visibility, and Resource sharing (see Table 2). 
Table 2: Themes and Supporting Responses from Fashionpreneur members

Theme Supporting Response

Power supply

Finances and Infrastructure

Resource sharing
"My major challenge is with the power supply."

"Power supply is a major challenge we face. Calculating the monthly payment for buying gas is outrageous, and this leads to financial challenges sometimes."

"Steady power supply is the main source."

"To me, electricity is the major resource in the fashion studio."

"once you have the capital, everything is achievable...I need a showroom that will impress my clients."

"no support from the government, we have to source for fund ourselves... the banks are giving out loans for SMEs now, but I'm not sure I'm ready for that now." "...our office space is small and not big enough to accommodate other departments in the company. Our production is limited by space and funds." "Our production and profit are limited by capital, and we've been leveraging on goodwill from suppliers to the level they can take the risk."

".... I have a lot of designs in my head, but I can't make them in different sizes because I don't have enough money." "getting funds has been a challenge, not until recently that banks are supporting small and medium scale businesses," ".... we've been working with what we have."

"My unique skills are my creativity and the ability to predict measurements from pictures."

“.... uh though my studio space is small. Still, I am willing to share my studio space with my other designers if the need is and if I am not using the studio space. I look forward to creating a workable ecommerce space for all." “...mmm, I don't mind sharing my managerial and my creative skills." 
"...I would like to train designers on the benefits of customer relationships because that is what is sustaining my business." "marketing team is needed to help us as designers because some of us are always on the machine sewing.."

Collaboration/ Benefits "collaboration is the uhh new money." "...collaboration helps you connect, it connected with the good goons in the industry and also improved my marketing skills network."

“.... everybody was not ready to do their part; it was not an effective collaboration as there was no result...." ".... has turned in to other fashion businesses and helped launched their brands...."

"I can't crack my brain to bring designs, and you say in conjunction with my brand. That's why I am not interested in collaboration with fashion designers but non-fashion designers."

"collaboration is the best strategy that can work for people.... If we work together, we will achieve more; even the bible says one will chase one thousand and two, ten thousand."

"my friend and I are planning to create a fashion hub but still battling with the issue of trust."

"collaboration is the best strategy that can work for people.... If we work together, we will achieve more; even the bible says one will chase one thousand and two, ten thousand....."

\section{Fashionpreneur Members - Challenges and Opportunities}

The challenges discovered from these findings are Power supply, finances and infrastructure. The opportunities are in the finances and infrastructure, resource sharing, and collaboration/benefits. I will go through the themes generated in the following section. 


\section{Power supply}

The primary issue identified by all the participants is a stable power supply. Unstable power supply leads to an increase in the cost of production as the business owners spend more on buying fuels for their generators. Ola said that “...power supply is the major challenge we face. Sustaining a fashion business in Lagos is really challenging because of the unstable power supply and the money used to fuel the generator. Their sewing facilities are run electricity; hence, the need for a stable power supply. An average Fashion designer has a generator because it is readily available to the masses.Per Dare, "To me, electricity is the major resource in the fashion studio". Effective production is dependent on how stable the power supply is. Yemi said, "steady power supply is the main source". Lara even believes that his monthly expense on gas is part of his financial challenge, “... calculating the monthly payment for buying gas is outrageous, and this leads to financial challenge sometimes". Extra expenses on finding an alternative source of energy is expensive and can lead to business failure. Eneh (2017) supported these findings when he reported that weak small businesses could not afford alternative electricity power sourcing in the face of the unstable electricity generation/supply situation in Nigeria. This challenging situation, in turn, has significantly reduced capacity utilization of small businesses, damages their equipment due to power surges, and ultimately lead to the failure of many small businesses. The companies that can afford the alternative of getting generators to lose product price competitiveness due to the exorbitant cost of production. Irregular electricity supply is a significant challenge in most African countries, and other challenges are demand and supply challenges, institutional and governance challenges, private investment obstacles, an unequal supply 
of energy, rolling blackouts, and grid maintenance and infrastructure challenges (Nel, 2019). These findings supported Ezinwa \& Ikechukwu's (2017) report that the most profound challenge of the Nigerian Fashion industry is the lack of stable power supply.

\section{Finances and Infrastructure}

Finances are needed to kickstart a business and to keep the business running. Infrastructure like studio space and showrooms are required to highlight the creativity of the designer's work. Ade said that “once you have the capital, everything is achievable...I need a showroom that will impress my clients." Chijioke (2016) concluded that one of the most critical factors that affect the business failures of most SMEs in Nigeria included factors such as inadequate infrastructure and finances. The government is not supporting these fashion businesses. Yemi said, "no support from the government, we have to source for fund ourselves... the banks are giving out loans for SMEs now, but I'm not sure I'm ready for that now." Lara expressed the set back in his business; he said, “...our office space is small and not big enough to accommodate other departments in the company. Our production is limited by space and funds." Finances dictate the number of clothes produced according to Odun, "Our production and profit are limited by capital, and we've been leveraging on goodwill from suppliers to the level they can take the risk". Aduke is also limited in productions because of finance she said: “.... I have a lot of designs in my head, but I can't make them in different sizes because I don't have enough money." Some other comments are "getting funds has been a challenge, not until recently that banks are supporting small and medium scale businesses," ".... we've been working with what we have." 
Sufficient capital to stay in business is unavailable to many SMEs in Nigeria, where SMEs are often forced to close because they are not able to access the necessary funds like bank loans and government funds (Neagu, 2016). Furthermore, the success of small businesses is reliant on the availability of funding (Cowling, Liu, Ledger, \& Zhang, 2015). Bazza, Maiwada, and Daneji (2014) pointed out that financial capital is the primary factor affecting the growth and development of SMEs in Nigeria. The extent to which the opportunities offered by SMEs are exploited and their contributions maximized in any economy depend on the enabling environment created through the provision of requisite infrastructural facilities (Ojo, 2006).

\section{Resource sharing}

An exciting aspect of this research is the unique resources the participants possess and are willing to share with other people. Ola posited that "my unique skills are my creativity and the ability to predict measurements from pictures"... " Lara said, “.... uh though my studio space is small. Still, I am willing to share my studio space with my other designers if the need is and if I am not using the studio space. I look forward to creating a workable e-commerce space for all." Lara also explained how he shared some office space with two (2) of his friends while starting his business. Odun said he lacked technical skills, but he has a resource to offer “....mmm, I don’t mind sharing my managerial and my creative skills". Dare showed his willingness to share what is sustaining his business “...I would like to train designers on the benefits of customer relationships because that is what is sustaining my business". Ade requested that the "marketing team is needed to help us as designers because some of us are always on the machine sewing". Marketing collaboration is needed to sustain their businesses. 
These responses are supported by Jayaweera (2015) when he reported that enterprise success results from teamwork and depends on the available resources, and the working environment. The inference from these findings is that small business enterprises must develop and exploit all available resources for long-term success. Small businesses function in an environment of reciprocal interaction of activities, associations, and relationships between people, materials resources, information, and other systems (Oginni \& Adesanya, 2013).

Sangar and Rangnekar (2014) reported that collaboration in developing countries aims to achieve mutually beneficial results under challenging conditions. Some of the other resources the fashion designers are interested in are: sharing showroom in a strategic location, getting a stylist to work with, partnering with a retailer, a male designer that makes men's wear, and someone who makes children's wears, and getting a workshop with a stable power supply. In developing countries, the exploiting of community spirit encourages individuals and businesses to focus on better consumption of market resources to join forces for a mutual need (Ratten, 2014).

\section{Collaboration/Benefits}

This study intends to explore the challenges, opportunities, and best practices in the collaborative communities of fashion design entrepreneurs in Nigeria. The participants explained the collaborative relationship they have experienced, and it has been for their competitive advantage. Lara posited that "collaboration is the uhh new money”. Ade said, “...collaboration helps you connect; it connected with the good goons in the industry and also improved my marketing skills network." She explained how she was in a collaborative partnership for some months but stopped because ".... everybody 
was not ready to do their part; it was not an effective collaboration as there was no result...."

Harris (2005) supported these findings when he reported that effective collaboration means working together efficiently and effectively for improved organizational performance, such as better-quality products, processes, and services. Ola posited about the free mentorship he offered his friends and ".... has turned in to other fashion businesses and helped launched their brands...." However, Ola said he is not ready to collaborate with another fashion designer because "I can't crack my brain to bring designs, and you say in conjunction with my brand. That's why I am not interested in collaboration with fashion designers but not non-fashion designers." Odun said that "collaboration is the best strategy that can work for people.... If we work together, we will achieve more; even the bible says one will chase one thousand and two, ten thousand." Odun is skeptical about collaborating with a friend, and he posited that "my friend and I are planning to create a fashion hub but still battling with the issue of trust". Trust is an essential factor while forming collaborative partnerships. Collins (2013) cited trust as the willingness to conquer cultural disparities and to work through other problems that arise in collaboration. Aduke discussed production efficiency and effectiveness when he said, "collaboration is the best strategy that can work for people, ...if we work together, we will achieve more." Odun also supported this and said "even the bible says one will chase one thousand and two, ten thousand". Fajuyigbe (2016) reported that collaboration is a severe missing link in many African countries, and it is needed for SME survival in Nigeria. 
Some of the benefits enjoyed by the Fashionpreneur participants are “...travelling together for business trips....co-hosting fashion show." Dare said that "there is double profit when you go into collaboration, and you will be able to meet with demands in a short time...., ....my market will be more visible when I partner with a known brand...." Collaboration also makes room for publicity. Yemi commented about the advertisement benefit she will derive from collaboration “....my partner's clients will also see my work on my partner's social media handle...." Ade posited, "If we collaborate and we post the pictures on social media, I have my followers that will see my partner's work on my page, same goes for my partner's work on the page too".

\section{Findings for Non-Fashionpreneurs}

The challenges discovered from this interview is power supply, and Finances and Infrastructure. The opportunities are in Finances and Infrastructure, Resource sharing, and Collaborations/Benefits. The findings revealed that these two groups are faced with the same challenges, and they are looking for the same opportunities. This suggests that the Fashionpreneur group still needs to look for ways to tackle this by themselves or involving external forces like the government or bigger fashion bodies.

Table 3: Themes and Supporting Responses from non-Fashionpreneur members

Theme Supporting Response

Power supply
"If you don’t have stable electricity, it will affect the
way you produce. You will use a manual machine
instead of the electric machine.”
“...since they bring light mostly at night, I try to stay
awake to finish up sewing."
".... I give my clients two weeks to finish up their cloth. I
know it can’t be that bad that they will not give us light in
two weeks."
"sewing without light is challenging.... we need light to
iron when sewing."




\begin{tabular}{|c|c|}
\hline Finances and Infrastructure & $\begin{array}{l}\text { "I need to upgrade my showroom to my customer's } \\
\text { taste." } \\
\text { "I would like to have a showroom to display my } \\
\text { creativity." } \\
\text { "If you have many ideas in your head and there's no } \\
\text { help forthcoming from the government in terms of the } \\
\text { fund if you are not a zealous person, it will die." } \\
\text { "... customers are not ready to pay for the services } \\
\text { rendered for them...." "we spend so much to make } \\
\text { garments, but customers are not ready to pay for the } \\
\text { extra charges incurred when we use fuel." } \\
\text { "People don't want to pay for the price of the style they } \\
\text { choose." }\end{array}$ \\
\hline Resource sharing & $\begin{array}{l}\text { "we have challenges with getting the right team to } \\
\text { work with..., I need a studio with a stable power } \\
\text { supply to save money on petrol and make my work } \\
\text { faster." } \\
\text { "...but I wish I can predict measurements." } \\
\text { ".... some state-of-the-art machines to make my work } \\
\text { faster." }\end{array}$ \\
\hline Collaboration & $\begin{array}{l}\text { "I've been able to meet up with deadlines through } \\
\text { collaboration." } \\
\text { "Your business will grow faster when you collaborate. } \\
\text { I've gotten more clients with good pay." }\end{array}$ \\
\hline
\end{tabular}

Non-Fashionpreneur Members - Challenges and Opportunities

The challenges discovered from these findings are Power supply, Finances, and Infrastructure. The opportunities are in the Finances and Instructure, Resource sharing, and collaboration/benefits. From the responses, it showed that the two groups - the Fashionpreneur and the non-Fashionpreneur group are faced with the same challenges and opportunities. I will go through the themes generated in the following section.

\section{Power supply}

The power supply is very erratic and affecting manufacturing companies. A lot is delayed when the power supply is epileptic. Sewing is delayed, and the cost of production increases due to finding alternatives to supply electricity. Taiwo said, "If you don't have stable electricity, it will affect the way you produce. You will use a manual machine 
instead of an electric machine." He mentioned about how he manages his time to maximize the when there is power supply. He said, “... since they bring light mostly at night, I try to stay awake to finish up sewing." Akin also explained how she manages her time to meet the customer's deadline; she said, “.... I give my clients two weeks to finish up their cloth. I know it can't be that bad that they will not give us light in two weeks." Ore opined that "sewing without light is challenging.... we need light to iron when sewing." Toyin and Akin complained about the extra cost incurred when they run on another source of electricity, and customers are not ready to pay more for this additional cost of production. Ezinwa \& Ikechukwu (2017) reported that most Nigerian citizens still depend on some other sources of energy, like fuel-wood combustion, which results in the emission of poisonous gaseous substances.

Adebiyi (2014) stated that $36 \%$ of production costs allocated to power generation by the members of the Manufacturers Association of Nigeria (MAN). Thus, $10 \%$ of members operated at $48.8 \%$ capacity, $60 \%$ were at varying phases of coma, while $30 \%$ had completely shut down. These are mostly medium to large entrepreneurs, how much more for small businesses. Some experts have claimed that this unreliable power supply appears to be the most challenging factor hindering human activities in developing countries (Olowofeso, 2011; Olaseni and Alade, 2012; Akanji, 2016).

\section{Finances and Infrastructure}

One common thing among all the participants is that they need a showroom that will make their work more visible. Ore said, "I need to upgrade my showroom to my customer's taste." Taiwo opined that "I would like to have a showroom to display my creativity". These comments show that even if they produce high-quality designs and these designs are not displayed, then it is a waste of effort. The essence of their creativity 
or designs is for their work to be more visible. Mandah and Ewurum (2012) presented that the government's failure to provide a conducive business environment and poor management of resources have influenced the development and performance of small businesses in Nigeria.

Toyin, Akin, and Taiwo lamented about their financial challenges. They said they started and sustained their businesses through personal savings. Taiwo opined, "If you have many ideas in your head and there's no help forthcoming from the government in terms of the fund if you are not a zealous person, it will die". Taiwo also said he would not advise a new business should take loans to start up because it is too early and because of the unrealistic conditions attached. Business owners need financial resources to launch and sustain their business ideas (Bouzahir \& Chakir, 2013).

They also mentioned the financial challenges they face from the customer's angle. Ore lamented that ".... customers are not ready to pay for the services rendered for them...." Toyin opined that "we spend so much to make garments, but customers are not ready to pay for the extra charges incurred when we use fuel". Akin said, "People don't want to pay for the price of the style they choose". Limited availability of financial resources, including credit and the interests of investors, restricts small business growth (Price et al., 2013).

\section{Resource sharing}

The designers are interested in sharing some resources to improve their business activities. Toyin opined that "we have challenges with getting the right team to work with..., I need a studio with a stable power supply to save money on petrol and make my work faster”. Akin offered her styling skill, “...but I wish I can predict measurements”. 
Taiwo needs “.... some state-of-the-art machines to make my work faster.” Ezinwa and Ikechukwu (2017) reported that a cloth-making industrialist city in Nigeria has clusters that collaborate to supply electric power generating sets and fuel as a backup substitute source of power supply. However, generator maintenance fees and fueling are too high and, in most cases, unaffordable.

\section{Collaboration/Benefits}

The designers shared how they are involved in collaboration and the benefits they have enjoyed. Ore said she is in collaboration with a male tailor to make male outfits as she is only making female outfits. She said she used to contract it out before now, but she told otherwise to save cost, hence, the initiation of the collaboration. Toyin and Akin said they collaborate with some other designers when they have lots of work to do with limited time. Toyin said, "I've been able to meet up with deadlines through collaboration". Taiwo talked about how he has enjoyed market visibility "your business will grow faster when you collaborate. I've gotten more clients with good pay."

These findings reveal that Nigerian Fashion entrepreneurs, both the Fashionpreneur members and non-members, are faced with similar challenges, as explained in the interviews. At the time of this research, there was no difference in the challenges and opportunities faced by these two groups of fashion design entrepreneurs. I will offer recommendations for the Fashionpreneur group in the next section. 


\section{CHAPTER FIVE}

\section{Conclusions}

\section{Outcomes and Implications}

The research provided four important themes to answer the three research questions, which are: what are the challenges faced by fashion designers in Nigeria? What are the opportunities for collaboration among fashion designers in Nigeria to solve the challenges? What are the resources required to create a collaborative community for resource sharing among fashion designers in Nigeria? From the responses of the participants, it was clear that they were concerned with power supply, finances and infrastructure, resource sharing, and collaboration. They also thought that they could overcome these challenges by collaborating with other fashion design entrepreneurs that have what they lack.

One very important aspect that interviewees pointed out as the backbone and the primary resource for fashion manufacturing is the power supply. The power supply is the backbone and the primary resource needed in the fashion manufacturing studio because many pieces of equipment use electricity. Unstable power supply means that designers must look for alternative power supply to keep up with manufacturing, which in turn leads to the prohibitive cost of production and the emission of poisonous gases that pollute the environment. This challenge is causing many small businesses to exit the marketplace. Nigeria is one of the world's largest producers of carbon emissions, which is strongly correlated with global warming (Ezinwa \& Ikechukwu, 2017). The smoke from a generator providing alternative power supply is not ecofriendly, and it is dangerous to human health. One conceivable way out of this significant challenge, I 
think, is for the government to provide an uninterrupted power supply. Power must be improved significantly to accommodate manufacturing activities for smooth operations.

The next daunting challenge faced by these designers is finances and infrastructures. These entrepreneurs shared how they need money for a befitting showroom to display their work, which can be achieved through finance and excellent infrastructure. Some of their business ideas were not productive because of a lack of finances; they were only able to make do with what they have. The female entrepreneurs also lamented how their clients were not ready to pay for the value of the design they chose. Though the bank is offering loans to SMEs, some of the designers ignored this option because of the conditions attached. These entrepreneurs are sourcing capital for themselves because the government support is insufficient.

Investigating best practices that promote the development, growth, and profitability of SMEs in Nigeria would require consolidated efforts and collaboration with other entrepreneurs (Chijioke, 2016). Resource sharing is cost-effective and makes manufacturing efficient. The participants shared the benefits they enjoyed in their past collaborations, like meeting up with deadlines. Designers were able to offset their insufficient resources for effectiveness. A lot is achieved in a shorter time when resources are shared. Resources like constant power supply, spacious workspace with a state-ofthe-art sewing equipment, marketing skills, and a showroom in a strategic place are the significant resources mentioned by the participants. These are the opportunities in collaboration. For the growth of their business, small businesses should locate themselves and offer or present resources lacking in their businesses.

\section{Recommendations for Actions}


Small business communities should unite and support each other through collaborations creating something of economic value via the sharing of resources for mutual benefits. Mandah and Ewurum (2012) presented that poor resource management and the government's failure to provide a favorable business environment has affected the growth and performance of small businesses in Nigeria. Contrary to Nigerian conditions, many Asian countries provide supportive public infrastructure for small businesses, either to offset inadequacies or to explore alternative ways to overcome the effects of lapses in infrastructure (Chijioke, 2016). These Asian networks guard their members by meeting their crucial needs in areas of finance, personnel, market information, equipment, and raw materials supplies (Mambula, 2002). When these strategies are applied in Nigeria, business survival and growth may emerge. The Fashionpreneur group should also see ways they can connect fashion designers for resource sharing. This connection is to ensure that the group fulfills her missions.

\section{Contribution to Knowledge}

This research work has contributed to resolving the tradition of inconsistencies associated with missed opportunities in collaboration. The research has, therefore, enlightened business communities on the benefits of collaborative entrepreneurship in Nigeria for business growth and performance. It will also serve as a revelation to the government, the Fashionpreneur group, and the Fashion Design Association of Nigeria (FADAN) on the variables that enhance the performance of small business communities in Nigeria. I will provide the Fashionpreneur group with a summary of the published result. I will also present a copy of the research to the FADAN so that they can use for 
further research. I will disseminate the result of the study through conferences, literature, training, and publication in journals and public libraries.

\section{Limitations}

This research work is limited to registered Fashionpreneur members and four nonmembers within Lagos State, Nigeria. These fashion designers reside in Lagos State, which is a subset of the broader community. Hence, its findings cannot be generalized to other

fashion entrepreneurs and other states in Nigeria. Another limitation is the fact that the time difference in scheduling the interviews limited the number of participants.

\section{Recommendations for further study}

This present study evaluates the collaborative entrepreneurship of small business communities in Nigeria. The recommendations for further research include getting more participants for a similar study, increasing geographic coverage within Nigeria, and interviewing more fashion designers. Future researchers should also consider new research on creating a directory of resources which will provide information about how and where fashion designers can access resources for collaborative purposes. 


\section{REFERENCES}

Adebisi, J. F., \& Gbegi, D. O. (2013). Effect of multiple taxation on the performance of small and medium scale business enterprises. (A study of West African Ceramics Ajeokuta, Kogi State). Mediterranean Journal of Social Sciences, 4(6), 323.

Ademola, I. S., \& Michael, A. A. (2012). Small scale businesses as a remedy to unemployment problem in Nigeria. International Journal of Scientific \& Engineering Research, 3(11), 1-6.

Adisa, T. A., Abdulraheem, I., \& Mordi, C. (2014). The Characteristics and Challenges of Small Businesses in Africa: An Exploratory Study of Nigerian Small Business Owners. Petroleum-Gas University of Ploiesti Bulletin, Technical Series, 66(4).

Afigbo, A. E., \& Okeke, C. S. (1985). Weaving tradition in Igboland. Weaving tradition in Igboland: History and mechanism of Igbo Textile Industry, 1-43.

African union: Fashionomics Africa supports launch of pan-African fashion initiative. (2019, Feb 21). Targeted News Service Retrieved from http://www.libproxy.wvu.edu/login?url=https://search-proquestcom.www.libproxy.wvu.edu/docview/2184436163?accountid=2837

Akanji O. O. (2016b) Nigeria: Between Governance and (under) Development. Analysing the Root of the Fractured Security. Conflict Studies Quarterly Issue 17, October 2016, pp. 3-16.

Ankoma, B. (1998). The Day Africa Came to London. New Africa. 368(36-38).

Anugwom, E. E. (2011). "Wetin We for Do?" Women Entrepreneurs and the Niger Delta Conflict. Journal of Small Business \& Entrepreneurship, 24(2), 243-252.

Audretsch, D. B., Kuratko, D. F., \& Link, A. N. (2015). Making sense of the elusive paradigm of entrepreneurship. Small Business Economics, 45(4), 703-712.

Austin, J. E. (2010). The collaboration challenge: How nonprofits and businesses succeed through strategic alliances (Vol. 109). John Wiley \& Sons.

Austin, J. E., \& Seitanidi, M. M. (2012). Collaborative value creation: A review of partnering between nonprofits and businesses: Part I. Value creation spectrum and collaboration stages. Nonprofit and Voluntary Sector Quarterly, 41(5), 726-758. 
Bardasi, E., Blackden, C.M. and Guzman, J.C. (2007), “Gender, entrepreneurship, and competitiveness in Africa", Chapter 1.4 of the Africa Competitiveness Report, June 26, The World Bank, Washington, DC.

Barnham, C. (2012). Separating methodologies? International Journal of Market Research, 54(6), 736-738.

Barrowclough, D., \& Kozul-Wright, Z. (2008). Voice, choice and diversity through creative industries: towards a new development agenda: Diana Barrowclough Zeljka Kozul-Wright. In Creative Industries and Developing Countries (pp. 12-45). Routledge.

Bazza, M. I., Maiwada, B. Y., \& Daneji, B. A. (2014). Islamic financing: A panacea to small-medium scale enterprises financing problems in Nigeria. European Scientific Journal, 10, 432-444. Retrieved from http://www.academicimpact.org

Berger, I. E., Lagarde, F., Cunningham, P. H., \& Drumwright, M. E. (2004). Social Alliances: Company/Nonprofit Collaboration. Social Marketing Quarterly, 5(3), 48-53.

Bhardwaj, B. (2014). Impact of education and training a performance of women entrepreneurs: a study in emerging market context. Journal of Entrepreneurship in Emerging Economies, 6(1), 38-52.

Bolton, B., \& Thompson, J. (2015). The Entirepreneur: The All-in-one Entrepreneurleader-manager. Routledge.

Bouzahir, B., \& Chakir, A. (2013). Entrepreneurs' access to venture capital in Moroccan’ s technology-based ventures: An exploratory study of the role of social capital. International Journal of Business and Social Science, 4(8), 144-161.

Bucklin, L.P. \& Sengupta, S. (1993). Organizing successful co-marketing alliances. Journal of Marketing, 57(2), 32-46.

Buowari, P. E. (2015). Factors required for small business sustainability in Nigeria. Doctoral Study. Minneapolis, Minnesota, United States: Walden University.

Bunger, A. C. (2013). Administrative coordination in nonprofit human service delivery networks: The role of competition and trust. Nonprofit and voluntary sector quarterly, 42(6), 1155-1175. 
Chijioke, M. I. (2016). Strategies to Sustain Small-and-Medium Sized Business Enterprises. Doctoral Dissertation. Walden University.

Cornforth, C., Hayes, J. P., \& Vangen, S. (2015). Nonprofit-public collaborations: Understanding governance dynamics. Nonprofit and Voluntary Sector Quarterly, 44(4), 775-795.

Coleman, A. \& Kofi, O. (2008). Outreach of profitability of microfinance institutions: The role of government. Journal of Economic Studies , 53 (3), 236-248.

Collins, K. H. (2013). The organizational factors influencing the building of collaborative culture: An examination of the evidence. University of Maryland University College.

Condie, J. (2012). Beyond rationalisations: Improving interview data quality. Qualitative Research in Accounting \& Management, 9(2), 168-193.

Cowling, M., Liu, W., Ledger, A, \& Zhang, N. (2015). What really happens to small and medium-sized enterprises in a global economic recession? UK evidence on sales and job dynamics. International Small Business Journal, 33, 488-513.

doi:10.1177/0266242613512513

Creswell, J. W. (2009). Research design: Qualitative, quantitative, and mixed methods approaches. Thousand Oaks, CA: Sage.

Cresswell, J. W., \& Plano Clark, V. L. (2011). Designing and conducting mixed method research. 2nd Sage. Thousand Oaks, CA, 201.

Dess, G. G., Lumpkin, G. T., \& Eisner, A. B. (2008). Strategic Management: Creating Competitive Advantages. In Dess, Gregory G, Lumpkin, G.T. and Taylor, Marilyn, L., Strategic Management: Text and Cases, 4-33, McGraw Hill.

Dickson, P. H., \& Weaver, K. M. (2011). Institutional readiness and small to medium-sized enterprise alliance formation. Journal of Small Business Management, 49(1), 126148.

De Turegano, T.H. (2008). Film culture and industry in Burkina Faso. In: D. Barrowclough and Z. KozulWright (eds.) Creative Industries and Developing Countries. New York: Routledge, 111-129. 
Ecubator (2001, June, 1). Defining the fashion entrepreneur. Ecubation. Retreived from http://ecubation.com/blog/passion-to-for-a-fashion-entrepreneur/

Edwards, P. (2000, April). Attitude Africa. Essence, 30(12).

Ekekwe, O. J. (2013). Relationship Between Institutional Frameworks and Growth of SMEs in Nigeria's Petroleum Industry (Doctoral dissertation, Walden University).

Ekpe, U., \& Nnochiri, G. (2009). Textile and fashion production skills for sustainable development in the Niger Delta. Global Journal of Humanities, 8(1\&2), 63-67.

Ekpe, I. (2011). Women entrepreneurs and economic development in Nigeria: Characteristics for success. International Journal of Business and Social Science, 2(1).

Eneh, O. C. (2017). the challenges of entrepreneurs in accelerating sustainable development in natural resource-rich Nigeria. Proceedings of the 18th International Academy of African Business and Development (IAABD) Conference, May 17-20, 2017, Georgia State University, Atlanta, USA]

Eno, M., \& Dammak, A. (2014). Debating the case study dilemma: Controversies and considerations. Veritas: The Academic Journal of St Clements Education Group, $5(3), 1-8$.

Ezinwa, V. C., \& Ikechukwu, A. E. (2017). Clothe Industry in Aba, Nigeria: an expository study. Technoscience Review, 8(2), 46-52.

Fajuyigbe, K. E. (2016). An exploratory study of the influence of leadership on SMEs survival in Nigeria (Doctoral dissertation, University of Phoenix).

Flew, T. (2013). Global creative industries. John Wiley \& Sons.

Franco, M., \& Haase, H. (2013). Firm resources and entrepreneurial orientation as determinants for collaborative entrepreneurship. Management Decision, 51(3), 680-696.

Garg, P., \& Garg, A. (2013). An empirical study on critical failure factors for enterprise resource planning implementation in Indian sector. Business Process Management Journal, 19, 496-514. doi:10.1108/14637151311319923

Ghanem, H. (2013). The role of micro and small enterprises in Egypt's economic transition. Global Economy \& Development Working Paper No. 55, Brookings Institution, Washington, DC. 
Ginsberg, F., \& Sinacore, A. L. (2013). Counseling Jewish women: A phenomenological study. Journal of Counseling \& Development, 91(2), 131-139.

González-Benito, J., \& González-Benito, Ó. (2005a). A study of the motivations for the environmental transformation of companies. Industrial Marketing Management, 34(5), 462-475.

González-Benito, J., \& González-Benito, Ó. (2005b). Environmental proactivity and business performance: an empirical analysis. Omega, 33(1), 1-15.

Gott, S. and Loughran, K. (eds.) (2010) Contemporary African Fashion. Bloomington: Indiana University Press.

Gray, B. (1989). Collaborating: Finding common ground for multiparty problems.

Gschwandtner, T., Gärtner, J., Aigner, W., \& Miksch, S. (2012). A taxonomy of dirty time-oriented data. In Multidisciplinary research and practice for information systems (pp. 58-72). New York, NY: Springer Publishing.

Guest, G., Bunce, A., \& Johnson, L. (2006). How many interviews are enough? An experiment with data saturation and variability. Field methods, 18(1), 59-82.

Guo, C., \& Acar, M. (2005). Understanding collaboration among non-profit organizations: Combining resource dependency, institutional, and network perspectives. Nonprofit and voluntary sector quarterly, 34(3), 340-361.

Gupta, A. K., \& Govindarajan, V. (2000). Knowledge flows within multinational corporations. Strategic management journal, 21(4), 473-496.

Hansen, K.T. (2013) Introduction. In K.T. Hansen and D.S. Madison (eds.) African Dress: Fashion, Agency, Performance. London: Bloomsbury, pp. 1-11.

Harper, M., \& Cole, P. (2012). Member checking: can benefits be gained similar to group therapy?. The qualitative report, 17(2), 510-517.

Harris, C. L. (2005). Collaboration for organization success: Linking organization support of collaboration and organization effectiveness. Ph.D. dissertation, University of North Texas, United States -- Texas. Retrieved January 22, 2011, from Dissertations \& Theses: Full Text.(Publication No. AAT 3206087).

Hays, D. G., \& Wood, C. (2011). Infusing qualitative traditions in counseling research 
designs. Journal of Counseling and Development, 89, 288-295

Hillman, A. J., Withers, M. C., \& Collins, B. J. (2009). Resource dependence theory: A review. Journal of management, 35(6), 1404-1427.

Ikebuaku, K., \& Dimbabo, M. (2018). Beyond entrepreneurship education. Business incubation and entrepreneurial capabilities. Journal of Entrepreneurship in Emerging Economies, 10, 154-174.doi:10.1108/JEEE-03-2017-0022

Ilkay, J. (2013). Identifying motives of mothers who purchase healthy convenience snacks for their children: A phenomenological study. Journal of Business Studies Quarterly, 5, 237-246. Retrieved from http://jbsq.org/

Inyang, B. J. (2013). Defining the role engagement of small and medium-sized enterprises (SMEs) in corporate social responsibility (CSR). International Business Research, 6, 123-132.

Jayaweera, T. (2015). Impact of work environmental factors on job performance, mediating role of work motivation: A study of hotel sector in England. International Journal of Business and Management, 10, 271-278. doi:10.5539/ijbm.v10n3p271

Josiane, C. (1998). Gender Issues in Micro-Enterprise Development. Geneva: ILO Publications June. http://www.ilo.org/enterprise.

Kao, J., and Stevenson, H. (1984). Entrepreneurship...... What it is and How to Teach it, Division of Research, Harvard Business School.

Kelley, T. (2005). The ten faces of innovation: IDEO's strategies for beating the devil's advocate \& driving creativity throughout your organization. Crown business.

Kessey, K. (2014). Micro credit and promotion of small and medium enterprises in information sector of Ghana: Lessons from experience. Asian Economic and Financial Review, 4, 768-780

Kim, Y. (2011). The pilot study in qualitative inquiry: Identifying issues and learning lessons for culturally competent research. Qualitative Social Work, 10(2), 190-206. 
Kjeldsen, J. and Nielson, K. (2000). The Circumstances of Women Entrepreneurs. Danish Agency for Trade and Industry, November. http://www.ebst.dk/publikationer/rapporter/women_entrepreneurs/kap04.html

Kohm, A., La Piana, D., \& Gowdy, H. (2000). Strategic restructuring: Findings from a study of integrations and alliances among nonprofit social service and cultural organizations in the United States, Chapin Hall Center for Children: 1-52.

Kornbluh, M. (2015). Combatting challenges to establishing trustworthiness in qualitative research. Qualitative Research in Psychology, 12(4), 397-414.

Lobato, R. (2010). Creative industries and informal economies: Lessons from Nollywood. International Journal of Cultural Studies, 13(4), 337-354.

Mambula, C. (2002). Perceptions of SME growth constraints in Nigeria. Journal of Small Business Management, 40, 59-65. doi:10.1111/1540-627X.00039

Mandah, C.W.A. \& Ewurum, U.J.F. (2012), Failure of small scale business in Nigeria: Causes and solutions - A case study of selected firms in Enugu State. Retrieved, http://www.unn.edu.ng/publications/files/images/MANDAH.CHIDINMA.A._1.pdf

Marshall, B., Cardon, P., Poddar, A., \& Fontenot, R. (2013). Does sample size matter in qualitative research?: A review of qualitative interviews in IS research. Journal of Computer Information Systems, 54(1), 11-22.

Mason, M. (2010, August). Sample size and saturation in $\mathrm{PhD}$ studies using qualitative interviews. In Forum qualitative Sozialforschung/Forum: qualitative social research 11(3).

Meller, E. (1996). Textile Technology in Nigeria: The historical Development in Science and Technology in Nigeria Fashion. The Courier, 157, 53-55.

Merriam, S. B. (2009). Qualitative research: A guide to design and implementation. San Francisco, CA: Jossey-Bass.

Mbaye, J. F. (2013). On the rogue practices of West African musical entrepreneurs. Rogue Urbanism: Emergent African Cities. Auckland Park: Jacana Media, and Cape Town: African Centre for Cities, 237-252.

Mbaye, J. F. (2015). Musical borderlands: A cultural perspective of regional integration in Africa. City, Culture and Society, 6(2), 19-26. 
Montero-Marin, J., Carrasco, J. M., Roca, M., Serrano-Blanco, A., Gili, M., Mayoral, F., \& Garcia-Campayo, J. (2013). Expectations, experiences, and attitudes of patience and primary care health professionals regarding online psychotherapeutic interventions for depression: Protocol for a qualitative study. BMC Psychiatry, 13(1), 64-79.

Moustakas, C. (1994). Phenomenological research methods. Sage.

Munn, Z., Porritt, K., Lockwood, C., Aromataris, E., \& Pearson, A. (2014). Establishing confidence in the output of qualitative research synthesis: the ConQual approach. BMC medical research methodology, 14(1), 108.

Naudé, W., Szirmai, A., \& Goedhuys, M. (2011). Innovation and entrepreneurship in developing countries. UNU.

Neagu, C. (2016). The importance and role of small and medium-sized businesses.

Theoretical and Applied Economics, 23, 331-338. Retrieved from

http://www.citefactor.org/journal/index/9008/theoretical-and-applied-economics

Nel, D. (2019). Sustainable Independent Power Production In Middle-Income African Countries. International Journal of Social Sciences and Humanity Studies, 11(2), $1-19$.

Obiwuru, T. C., Okwu, A. T., Akpa, V. O., \& Nwankwere, I. A. (2011). Effects of Leadership on organizational performance: A survey of selected small and medium scale enterprises in Ikosi-Ketu council development area of Lagos State, Nigeria. Australian Journal of Business and Management Research, 1(7), 100-111.

Oginni, B. O., \& Adesanya, A. S. (2013). Business environmental factors: Implications on the survival and growth of business organisations in the manufacturing sector of Lagos metropolis. Business and Management Research, 2(3), 146-155. doi:10.5430/bmr.v2n3p146

Ojo, J.A.T. (2006). Using SMEs To Achieve Millennium Development Goals: Challenges and Prospects. Covenant Journal of Business and Social Sciences, 1(1):1-11.

Olaseni M. and Alade W. (2012) Vision 20:20: The challenges of infrastructural development in Nigeria. Journal of Sustainable Development. 5(2), 63-76. 
Old traditions, new labels [analysis]. (2018, Nov 29). AllAfrica.Com Retrieved from http://www.libproxy.wvu.edu/login?url=https://search-proquestcom.www.libproxy.wvu.edu/docview/2139511848?accountid=2837

Olowofeso O. (2011) Challenges in using molecular markers in animal breed diversity study in Nigeria. Proc. 16th Ann. Conf. of Anim. Sci. Asso. Of Nig. K.S.U Anyigba, Nigeria. 12-15 Sept. Pp.49-52.

Onwuegbuzie, A. J., \& Byers, V. T. (2014). An exemplar for combining the collection, analysis, and interpretations of verbal and nonverbal data in qualitative research. International Journal of Education, 6(1), 183.

Oyeku, O., Oduyoye, O., Asikhia O., \& Elemo, G. N. (2014). On entrepreneurial success of small and medium enterprises (SMEs): A conceptual and theoretical framework. Journal of Economics and Sustainable Development, 5(16), 14-23. Retrieved from www.iiste.org

Parker, S. C. (2009). The economics of entrepreneurship. Cambridge University Press.

Pfeffer, J., \& Salancik, G. R. (2003). The external control of organizations: A resource dependence perspective. Stanford University Press.

Pittman, L. (2019). Promoting Community Engagement and Integration: Strategies of Collaboration Used in Socially Inclusive Art Centers across the United States (Doctoral dissertation, American University).

Pratt, A. C. (2007). The music industry and its potential role in local economic development: the case of Senegal: Andy C. Pratt. In Creative Industries and Developing Countries (pp. 138-153). Routledge.

Proulx, K. E., Hager, M. A., \& Klein, K. C. (2014). Models of collaboration between nonprofit organizations. International Journal of Productivity and Performance Management, 63(6), 746-765.

Price, L., Rae, D., \& Cini, V. (2013). SME perceptions of and responses to the recession. Journal of Small Business and Enterprise Development, 20, 484-502.

Ratten, V. (2014). Encouraging collaborative entrepreneurship in developing countries: the current challenges and a research agenda. Journal of Entrepreneurship in Emerging Economies, 6(3), 298-308. 
Ray, A. \& Mondal, S. (2017). Study of collaborative PRM business model for sustainability. Benchmarking: An International Journal, 24(7), 1891-1911.

Roschenthaler, U. \& Schulz, D. (eds.) (2016). Cultural Entrepreneurship in Africa. New York: Routledge.

Rowley, J. (2012). Conducting research interviews. Management research review, 35(3/4), 260-271.

Rubin, H. J., \& Rubin, I. S. (2011). Qualitative interviewing: The art of hearing data. Sage.

Sangar, R., \& Rangnekar, S. (2014). Role satisfaction and entrepreneurship: An approach to analyze the dynamics of relationships. Journal of Entrepreneurship in Emerging Economies, 6(2), 122-139.

Sarker, S., Xiao, X., \& Beaulieu, T. (2013). Guest editorial: qualitative studies in information systems: a critical review and some guiding principles. MIS quarterly, 37(4), iii-xviii.

Scheff, J., \& Kotler, P. (1996). How the arts can prosper through strategic collaborations. Harvard Business Review, 74, 52-62.

Seidman, I. (2006). Interviewing as qualitative research. New York, NY: Teachers College Press.

Seidman, I. (2013). Interviewing as qualitative research: A guide for researchers in education and the social sciences. New York, NY: Teachers College Press.

Seitanidi, M. M., \& Ryan, A. (2007). A critical review of forms of corporate community involvement: from philanthropy to partnerships. International Journal of Nonprofit and Voluntary Sector Marketing, 12(3), 247-266.

Sharma, A., Dua, S., \& Hatwal, V. (2012). Micro enterprise development and rural women entrepreneurship: way for economic empowerment. Arth Prabhand: A Journal of Economics and Management, 1(6), 114-127.

Shane, S., \& Venkataraman, S. (2000). The promise of entrepreneurship as a field of research. Academy of management review, 25(1), 217-226.

Shea, P. (1992). Textile Technology in Nigeria. Practical Manifestations in G.T. Emeagwali (ed),: The Historical Development of Science and Technology in Nigeria. Edwin Mellen 
Shehu, A., Ibrahim, M. A., Mat, N., Nasiru, A., Popoola, O., Muhammad, M., \& Kura, K. M. (2013). The mediating effect between some determinants of SME performance in Nigeria. Management, 3(4), 237-242.

Shipley, J. W. (2013). Living the Hiplife: celebrity and entrepreneurship in Ghanaian popular music. Duke University Press.

Singh, L. (2011). Accuracy of web survey data: The state of research on factual questions in surveys. Information Management and Business Review, 3(2), 48-56.

SMEDAN. (2013). SMEDAN and national bureau of statistics collaborative survey: Selected findings 2013. Abuja: SMEDAN. Retrieved from Small and Medium Enterprises Development Agency of Nigeria.

Sowa, J. E. (2009). The Collaboration Decision in Non-profit Organizations: Views from the Front Line. Non-profit and Voluntary Sector Quarterly 38(6), 1003-25. https://doi.org/10.1177/0899764008325247.

Stern, C. (2015). Corporate Social Responsibility \& the Arts. Washington, D.C.: Animating Democracy.

Stevens, S. K. (2008). Nonprofit lifecycles: Stage-based wisdom for nonprofit capacity. Wayzata, MN: Stagewise Enterprises.

Stierand, M. B., \& Dorfler, V. (2010). Research in brief: Reflecting on phenomenological study of creativity and innovation in haute cuisine. International Contemporary Hospitality Management, 24, 946-957. doi:10.1108/09596111211247254

Tsasis, P. (2009). The social processes of interorganizational collaboration and conflict in nonprofit organizations. Nonprofit management and leadership, 20(1), 5-21.

United Nation (2006). Entrepreneurship and e-Business Development for Women. Thailand: United Nations Publication.

United Nations Conference on Trade and Development (UNCTAD). (2010). Creative Economy Report 2010: Creative Economy-A Feasible Development Option.

Vangen, S., \& Huxham, C. (2003). Nurturing collaborative relations: Building trust in interorganizational collaboration. The Journal of applied behavioral science, 39(1), 5-31. 
Vock, M., Van Dolen, W., \& Kolk, A. (2013). Changing behaviour through businessnonprofit collaboration? Consumer responses to social alliances. European Journal of Marketing, 47(9), 1476-1503.

Webb, J. W., Ireland, R. D., \& Ketchen Jr, D. J. (2014). Toward a greater understanding of entrepreneurship and strategy in the informal economy. Strategic Entrepreneurship Journal, 8(1), 1-15.

Weinstein, L. (2010). The Design, Implementation and Management of Social Alliances for Arts-and Culture-Oriented Organizations. International Journal of Arts Management, 12(3), 31.

Yan, J., \& Sorenson, R. L. (2003). Collective entrepreneurship in family firms: The influence of leader attitudes and behaviors. New England Journal of Entrepreneurship, 6(2), 37-51.

Zucker, L. G. (1987). Institutional theories of organization. Annual review of sociology, 13(1), 443-464. 
Dear Participant,

This letter is a request for you to take part in a research project - Collaborative Entrepreneurship and Building Small Business Communities in The Nigerian Fashion Design Industry. This project is being conducted by Damilola Fasinu in the Design \& Merchandising Department at WVU under the supervision of Dr. Jones, an Assistant Professor at WVU in the Design \& Merchandising Department, to fulfil requirements for a Master's Degree in Research.

If you decide to participate, you will be asked to discuss the challenges, opportunities, and best practices in the collaborative relationships you have been involved. Your participation in this project will take approximately $15-30$ minutes. You must be at least 3 years in operation to participate. You must be 18 years of age or older to participate.

Your involvement in this project will be kept as confidential as legally possible. All data will be reported in the aggregate. You will not be asked any questions that could lead back to your identity as a participant. Your participation is completely voluntary. You may skip any question that you do not wish to answer, and you may discontinue at any time. West Virginia University's Institutional Review Board approval of this project is on file.

If you have any questions about this research project, please feel free to contact me at $+1304-216-5297$ or by e-mail at dtf0002@mix.wvu.edu. If you have any questions about your rights as a research participant, please contact the WVU Office of Human Research Protection by phone at $+1304-293-7073$ or by email at IRB@mail.wvu.edu.

I hope that you will participate in this research project, as it could help us better understand recommend best practices in creating a successful collaborative relationship and how collaborative partnerships can be used for the designer's competitive advantage. Thank you for your time and consideration.

Sincerely,

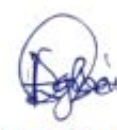

Damilola Fasinu

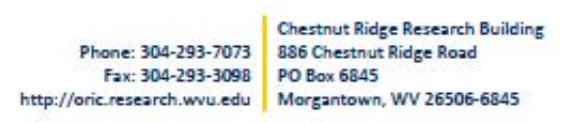

Page | 1 


\section{APPENDIX B}

\section{Interview Protocol}

I will introduce the interview to set the stage

Listen to responses and paraphrase as needed.

Ask probing questions as applicable.

Wrap up the interview, thanking the participants

Scheduling a follow-up member checking interview
There is an alarming rate of failure in small businesses in Nigeria, which influences the unemployment level that affects the local and national economy negatively. Collaboration for SMEs may be crucial for support and resources for survival

1. Tell me about your business?

2. What challenges have you faced in the time past? R1

3. How did you overcome the challenges? R1

4. Have you been involved, or are you presently in any collaborative relationship? R2

5. If yes, how was it initiated? If No, Why? R2

6. What benefits do you enjoy from collaboration? R2

7. What shared resources do you think will bring more success to your business and make your work more visible? R2

8. Tell me about the unique skills, qualifications, and capital/resources you have and those lacking? R3

9. Tell me how you have pursued relationships that would specifically help enhance the already held resources and/or offset their deficiencies. R3.

10. Any other ideas not discussed in this interview that might benefit the future?

Script: I want to thank you for offering to participate in this research study and the opportunity of permitting me to conduct this scheduled interview.

Script: Now, I will like to schedule a follow-up member checking interview in the next two weeks.

\section{Follow up Member Checking Interview}

Thank you for honoring my invitation for this follow-up member checking the interview.
Script: The copy of the documents I just sent to your mail is a summary of an interpretation of your responses based on the previous interview. Please, it is significant that you follow as we review together to ensure accuracy, consistency, of my interpretations. 
Share a copy of the concise synthesis for each interview question.

Probe as applicable Share a copy of the concise synthesis for each interview question.

Probe as applicable Share a copy of the concise synthesis for each interview question.

Probe as applicable Share a copy of the concise synthesis for each interview question.

Probe as applicable Share a copy of the concise synthesis for each interview question.

Probe as applicable Share a copy of the concise synthesis for each interview question.

Probe as applicable Share a copy of the concise synthesis for each interview question. Probe as applicable
1. Tell me about your business? Do you mean (check with the answers provided)

2. What challenges have you faced in the time past? Do you mean (check with the answers provided)

3. How did you overcome the challenges? Do you mean (check with the answers provided)

4. Have you been involved, or are you presently in any collaborative relationship? Do you mean (check with the answers provided)

5. If yes, how was it initiated? If No, Why? Do you mean (check with the answers provided)

6. What are the benefits you enjoy from collaboration? Do you mean (check with the answers provided)

7. What shared resources do you think will bring more success to your business and make your work visible? Do you mean (check with the answers provided)

8. Tell me about the unique skills, qualifications, and capital/resources you have and those lacking. Do you mean (check with the answers provided)

9. Tell me how you have pursued relationships that would specifically help enhance the already held resources and/or offset their deficiencies. Do you mean (check with the answers provided)

10. Any other ideas not discussed in this interview that might benefit the future? 